\title{
Y PANORAMA DA ALFABETIZAÇÃO NO BRASIL: UMA ANÁLISE A PARTIR DOS RESULTADOS DA AVALIAÇÃO NACIONAL DA ALFABETIZAÇÃO 2016
}

\author{
Fabiana de Assis Alves ${ }^{\mathrm{I}}$
}

Ticiane Bombassaro Marassi ${ }^{\text {II }}$

http://dx.doi.org/10.24109/9786558010074.ceppe.v3a2

\section{RESUMO}

Este artigo tem como objetivo discutir e contextualizar os resultados obtidos na Avaliação Nacional da Alfabetização (ANA) de 2016. A ANA é uma avaliação de larga escala que mensura os níveis de alfabetização e letramento em Língua Portuguesa e alfabetização em Matemática das crianças matriculadas no $3^{\circ}$ ano do ensino fundamental. Inicialmente, são apresentados e discutidos os conceitos de alfabetização para as escalas de Leitura e de Matemática. Com base nessas definições, é traçado um panorama geral sobre a alfabetização em Língua Portuguesa e em Matemática no País e são apresentados resultados agregados por grandes regiões, unidades da Federação, rede e localização, além de exploradas algumas relações entre os índices de alfabetização e os indicadores contextuais das escolas e dos municípios. Os resultados mostram que aproximadamente $22 \%$ dos estudantes do $3^{\circ}$ ano não eram alfabetizados em Língua Portuguesa e 54\% não cumpriram as expectativas de aprendizagem esperadas em Matemática. Nas regiões Norte e Nordeste e nas áreas rurais, o resultado apresenta um

\footnotetext{
Doutora em Economia pela Universidade Católica de Brasília (UCB) e Mestre em Estatística pela Universidade Federal de Minas Gerais. Atua como pesquisadora do Instituto Nacional de Estudos e Pesquisas Educacionais Anísio Teixeira (Inep) e desenvolve estudos e pesquisas sobre alfabetização, qualidade da educação e financiamento educacional.

II Doutora em Educação, História e Política e Mestre em Educação pela Universidade Federal de Santa Catarina (UFSC). É pesquisadora do Instituto Nacional de Estudos e Pesquisas Educacionais Anísio Teixeira (Inep) e desenvolve estudos e pesquisas sobre educação infantil e alfabetização.
} 
quadro ainda mais preocupante. Há fortes indícios de uma associação positiva entre o índice de alfabetização da escola e o nível socioeconômico dos estudantes atendidos por ela. Também se observa uma relação direta entre o nível de alfabetização da instituição e o seu índice de adequação da formação do corpo docente. Por fim, nota-se que os municípios com maior Índice de Desenvolvimento Humano Municipal (IDHM) e maior produto interno bruto per capita tendem a apresentar melhores índices de alfabetização, enquanto aqueles com maior desigualdade na distribuição da renda tendem a apresentar resultados piores.

Palavras-chave: avaliação de larga escala; alfabetização; leitura; língua portuguesa; matemática; proficiência.

\section{INTRODUÇÃO}

A Avaliação Nacional da Alfabetização (ANA) terminou seu ciclo no ano de 2016 com o encerramento das aplicações no $3^{\circ}$ ano do ensino fundamental. Segundo anunciado a partir da publicação da Base Nacional Comum Curricular ${ }^{1}$ (BNCC) e efetivado na Portaria Inep no 366, de 29 de abril de 2019, o processo de alfabetização será avaliado no $2^{\circ}$ ano do ensino fundamental, ainda que as expectativas de aprendizagem precisem ser ajustadas. Essa alteração parece atender à expectativa de construção de indicadores que permitam a intervenção em escolas de baixo desempenho, a fim de que possam alcançar padrões de aprendizagem mais adequados ao final do ciclo de alfabetização ${ }^{2}$. Ao mesmo tempo, demonstra uma concepção particular de alfabetização, possivelmente diminuindo as expectativas, haja vista que não será possível, para testes aplicados aos estudantes do $2^{\circ}$ ano, estabelecer critérios similares aos utilizados para o $3^{\circ}$ ano do ensino fundamental. Assim, torna-se importante esclarecer quais conceitos de alfabetização podem impactar as medidas das avaliações educacionais e, especialmente, determinar novas políticas para alcançar melhores desempenhos.

Na última edição da ANA, ocorrida no ano de 2016, participaram quase $50 \mathrm{mil}$ escolas, sendo que aproximadamente 40 mil delas tiveram uma taxa de participação de

\footnotetext{
1 A Base Nacional Comum Curricular não traz definição sobre a etapa da avaliação. Seu texto determina que o processo de alfabetização deve estar concretizado no $2^{\circ}$ ano do ensino fundamental. A alteração da etapa de avaliação se deu por meio da Portaria Inep $n^{\circ} 366$, de 29 de abril de 2019. A Portaria determina a execução de uma avaliação amostral dos estudantes de segundo ano. Por outro lado, não houve ato oficial de extinção da Avaliação Nacional da Alfabetização, aplicada no $3^{\circ}$ ano do ensino fundamental, que teve sua última edição em 2016.

2 O ciclo de alfabetização foi definido pelo Parecer CNE/CEB no 11/2010, que estabelece as Diretrizes Curriculares Nacionais para o ensino fundamental de 9 anos.
} 
pelo menos $80 \%$ de seus estudantes matriculados no $3^{\circ}$ ano do ensino fundamental ${ }^{3}$. Explorados em números no Relatório SAEB/ANA 2016: Panorama do Brasil e dos Estados, publicado em 2018, os resultados chegaram à mídia como uma avalanche de notícias ruins a respeito da situação da alfabetização dos estudantes no País.

De fato, pouco avançamos em alguns anos de políticas nacionais de alfabetização, sujeitas a trocas de governo e alterações em programas que buscavam garantir que os estudantes alcançassem bons níveis de alfabetização ao final do ciclo. Contudo, a avaliação foi um importante passo dado pelo Pacto Nacional pela Alfabetização da Idade Certa (Pnaic) $)^{4}$, lançado no ano de 2012, que previa a realização de medições anuais do nível de alfabetização dos estudantes ao final do $3^{\circ}$ ano.

Inviabilizada como edição anual ${ }^{5}$, a avaliação teve três aplicações: em 2013, como estudo experimental e, posteriormente, em 2014 e em 2016. Os resultados nacionais observados nas duas últimas edições praticamente não se alteraram. Observou-se apenas um aumento de aproximadamente $2 \%$ nos níveis mais elevados das escalas de Leitura e Matemática, bem como a manutenção de pouco mais de $20 \%$ dos estudantes no nível mais baixo dessas duas escalas.

Esses resultados não podem ser encarados como um fracasso da política de alfabetização implementada. Há muitas análises necessárias para determinar se houve avanço na aprendizagem dos estudantes do ciclo de alfabetização em diversos níveis e sua não realização pode consolidar um discurso de colapso geral das escolas e dos programas do Ministério da Educação, o que eventualmente pode não ser verdade. Ainda que necessária, não é essa a proposta deste estudo.

O objeto do estudo que expomos neste texto é complexo. Ao longo dos últimos anos, pesquisadores da área discutem propostas para a alfabetização, creditando o sucesso na aquisição da língua a uma série de fatores, especialmente à ação da escola sobre a aprendizagem (Soares, 2017; Oliveira, 2000; Brasil. Congresso Nacional, 2007). Todavia, os fatores apresentados por cada um desses teóricos como sendo determinantes são tão diversos quanto o próprio contexto de inserção das escolas. Um fato, contudo, permanece preponderante na discussão sobre a alfabetização em Língua Portuguesa e em Matemática e sobre a eficácia escolar em geral: a condição

3 A Lei $\mathrm{n}^{\mathrm{o}}$ 13.005, de 25 de junho de 2014, estabelece no seu art. 11, inc. I, § $1^{\circ}$, que o sistema de avaliação da educação básica produzirá indicadores de rendimento escolar, "referentes ao desempenho dos(as) estudantes apurado em exames nacionais de avaliação, com participação de pelo menos 80\% (oitenta por cento) dos(as) alunos(as) de cada ano escolar periodicamente avaliado em cada escola, e aos dados pertinentes apurados pelo censo escolar da educação básica.” (Brasil, 2014).

4 O Pnaic foi lançado no ano de 2012 pela Portaria $n^{\circ}$ 867, de 4 de julho de 2012. Algumas alterações nos seus objetivos foram feitas posteriormente pelas Portarias $\mathrm{n}^{0} 4$, de 4 de janeiro de 2018 e $\mathrm{n}^{\circ} 1.144$, de 10 de outubro de 2016.

5 Parecer técnico dos servidores da Diretoria de Avaliação da Educação Básica (Daeb/Inep) explicitou a necessidade de intervalos maiores para aferição dos avanços alcançados na área e acabaram incluindo a avaliação, no ano de 2013, no sistema de avaliação da educação básica, bianual, por meio da Portaria $\mathrm{n}^{\mathrm{o}} 482$, de 7 de junho de 2013. 
socioeconômica dos estudantes tem impacto na trajetória escolar, exigindo que as instituições se empenhem na conquista dos objetivos de aprendizagem, especialmente aquelas que atendem populações mais carentes.

O debate sobre a condição socioeconômica dos estudantes esteve pautado em dois importantes relatórios (Coleman et al., 1966; Central Advisory Council for Education, 1967) que destacam em seus resultados que, no contexto da pesquisa realizada, o nível socioeconômico dos alunos é um dos principais determinantes do sucesso escolar, em detrimento da estrutura das escolas, de seus processos internos e da qualificação de seus professores. A partir de então, a pesquisa em eficácia escolar começou a analisar qual a importância da escola no contexto em que grande parte dos resultados poderia ser previsto tomando por referência o perfil socioeconômico dos estudantes atendidos pela escola.

Contudo, os resultados a respeito da alfabetização no Brasil são extraídos apenas da avaliação em larga escala, como por exemplo a ANA, cujo desenho não permite evidenciar elementos sobre a prática pedagógica e outros fatores que possam influenciar os processos de ensino-aprendizagem e a sua eficácia. A avaliação possui um teste cognitivo, mas não avançou na proposta do seu documento básico ${ }^{6}$ de aplicação de questionários, inviabilizando, portanto, a mensuração do efeito das variáveis de contexto e das práticas pedagógicas sobre os resultados dos estudantes.

Este artigo, por sua vez, não tem como objetivo avançar na identificação dos principais determinantes do sucesso escolar, mas mapear os resultados obtidos na avaliação em larga escala e sua relação com alguns indicadores de contexto das escolas e dos municípios, a fim de que, em um próximo momento, sejam estudados mais a fundo os insumos escolares que afetam o resultados dos estudantes, em um cenário de contextos socioeconômicos distintos. Interessa saber, no próximo momento desta pesquisa, quais razões levam escolas inseridas em contextos de baixo nível socioeconômico a alcançarem o sucesso no processo de alfabetização e, também, como escolas inseridas em contextos de alto nível socioeconômico fracassam nesse campo.

Esse debate é interessante devido ao momento atual em que emerge a atribuição de culpa à escola e às práticas pedagógicas empregadas pelo fracasso escolar, traduzidas de maneira simplista em métodos, sobretudo na alfabetização. Ao apresentarmos uma relação entre o resultado dos estudantes e os aspectos contextuais mais amplos, como o nível socioeconômico e a formação docente, trazemos luz à ideia de que as diferenças existentes entre os desempenhos não consistem apenas em falhas metodológicas, mas também em influências maiores no processo ensino-aprendizagem, que precisam ser observadas pelos formuladores de políticas.

\footnotetext{
${ }_{6}$ O documento básico da ANA foi publicado no ano de 2013 contendo as principais informações sobre a avaliação. Em seção específica, o documento propunha a aplicação de questionários contextuais abordando os eixos de infraestrutura, formação de professores, gestão escolar e práticas pedagógicas.
} 
Ao mesmo tempo, a investigação desenhada para a próxima etapa desta pesquisa - analisar as instituições que se destacam em contextos de baixo nível socioeconômico ou as que fracassam mesmo possuindo melhores condições - pode nos levar a compreender melhor a influência das práticas pedagógicas no alcance das expectativas de aprendizagem. Essa é, sobretudo, uma maneira de lançar luz sobre um debate que simplifica em excesso as dinâmicas educacionais e se encontra traduzido na nova Política Nacional de Alfabetização (PNA) ${ }^{7}$.

Os dados apresentados nessa primeira etapa da pesquisa auxiliam a compreensão de quão pouco essa política considerou as evidências trazidas pela avaliação. O panorama apresentado revela que o desempenho dos estudantes na área de Matemática ao final de três anos de escolarização é muito baixo, com pouco mais da metade dos estudantes não atingindo as expectativas de aprendizagem. $\mathrm{Na}$ área de Leitura, o percentual de estudantes com desempenho inadequado foi bem menor, atingindo cerca de um quinto dos estudantes dessa etapa. Assim, são apresentadas as análises sobre fatores macrocontextuais e o desempenho dos estudantes nas escolas avaliadas, tomando por base os resultados nos testes de Leitura e Matemática ${ }^{8}$.

Este estudo está organizado em três seções. A primeira traz algumas considerações importantes sobre a ANA e a definição dos níveis esperados de conhecimento nas áreas de Leitura e de Matemática para um estudante matriculado no $3^{\circ}$ ano do ensino fundamental. A segunda seção traz um panorama geral da alfabetização no País, além de resultados agregados por grandes regiões, unidades federativas (UFs), municípios, rede e localização. A terceira explora relações entre os índices de alfabetização e alguns indicadores de contexto das escolas e dos municípios. Por fim, são feitas as considerações finais sobre os resultados encontrados.

\section{SUCESSO ESCOLAR E EXPECTATIVA DE APRENDIZAGEM}

Cabe, primeiramente, dizer algo sobre o sucesso das escolas no processo de alfabetização ou sobre qual seria o padrão de desempenho na avaliação da alfabetização que representasse as expectativas mínimas de aprendizagem.

É preciso reconhecer que as avaliações em larga escala buscam um diagnóstico das redes de ensino, pressupondo que há uma expectativa a ser alcançada por cada

\footnotetext{
A PNA foi instituída pelo Decreto $\mathrm{n}^{\circ}$ 9.765, de 11 de abril de 2019, e define que os processos de alfabetização apoiados pelo Ministério da Educação serão baseados "em evidências científicas [...]." (Brasil, 2019). Em resumo, fundamenta na psicologia cognitiva o uso do método fônico na solução dos problemas da alfabetização no País.

8 Optou-se por não utilizar os resultados em Escrita, no componente de Língua Portuguesa. Isso significa, portanto, reconhecer que o diagnóstico de alfabetizado teria que pressupor um conhecimento em ambos os componentes, assumindo a decisão de tratar, neste texto, o desempenho dos estudantes apenas como "insuficiente", não podendo qualificar o estudante como "não alfabetizado".
} 
uma delas. Se essa expectativa é declarada nos meios oficiais, acaba se tornando natural que as redes busquem maneiras para conquistar esse objetivo, fornecendo às instituições de ensino condições que as levem a garantir o direito dos estudantes de aprender o que se considera adequado em cada etapa escolar.

Tecnicamente, os padrões ou níveis de desempenho são categorias definidas a partir de "cortes" na escala de proficiência de uma área do conhecimento, por meio da Teoria de Resposta ao Item (TRI) e do estabelecimento de agrupamentos de perfis de desempenho descritos por competências e habilidades provavelmente desenvolvidas pelos estudantes. Esses padrões/níveis de desempenho seguem uma ordenação contínua e progressiva, sendo normalmente definido um nível de aprendizado que é considerado "adequado" ou "suficiente" num determinado ano ou etapa de ensino e área do conhecimento. A definição do nível "adequado", "proficiente" ou "suficiente" de aprendizado é baseada na interpretação pedagógica da escala de proficiência e estabelece o que se espera que os alunos dominem em termos de competências e habilidades em cada área de conhecimento em um determinado ano/etapa de ensino. (Bof, 2016, p. 13).

O que ocorre, então, se não há declaração de expectativa? A expectativa não é uma entidade genérica a ser definida com base em opções a cada gestão ou governo. É preciso registrar que toda a avaliação de larga escala se baseia nos parâmetros de currículo que o país adota, buscando refletir na sua produção essa expectativa de aprendizagem. Sendo assim, qualquer pesquisador poderá fazer uma análise dos referenciais curriculares adotados em seu País, estado ou município e ter clara a expectativa de aprendizagem a qual nos referimos.

Diversas entidades se dedicaram a essa tarefa no que se refere aos dados do Sistema Nacional de Avaliação da Educação Básica (Saeb). Conforme apresenta Bof (2016, p. 14):

O Saeb não apresenta uma definição oficial sobre os padrões de desempenho dos estudantes em suas avaliações, nem estabelece o nível ou padrão "adequado" ou "suficiente" de aprendizado em cada área do conhecimento e ano/etapa de ensino avaliado. Não obstante, vários sistemas educacionais e algumas organizações se debruçaram sobre essa questão e definiram tais níveis com base nas escalas de proficiência do Saeb. Na revisão da literatura e de documentos de sistemas de avaliação estaduais, foram identificados 14 sistemas de avaliação que definiram e utilizam padrões de desempenho para o $5^{\circ}$ e o $9^{\circ}$ anos do ensino fundamental em Língua Portuguesa (Leitura) e Matemática (Quadro 1), uma organização da sociedade civil - o Todos pela Educação (TPE) - e o Saeb especificamente na edição de 2003. Verificou-se que geralmente são definidos quatro níveis ou padrões de desempenho, embora com diferentes nomenclaturas e critérios de "corte" [...].

A autora se refere ao Saeb quando explica as definições dadas ao $5^{\circ}$ e $9^{\circ}$ ano do ensino fundamental. Embora essa reflexão se dê sobre os níveis da escala da Avaliação 
Nacional do Rendimento Escolar/Avaliação Nacional da Educação Básica (Anresc/ Aneb) ${ }^{9}$, o mesmo ocorre com a escala de alfabetização, que não conta com definição oficial sobre o nível a ser considerado adequado na avaliação desde a sua criação.

Esforços no sentido de tornar público um "ponto de corte" para as escalas do Saeb ocorrem por parte de várias instituições que utilizam os dados do sistema de avaliação. Organizações e plataformas diversas operam no sentido de estabelecer aquilo que oficialmente se buscava evitar impor: o ponto das escalas em que se poderia afirmar que os estudantes alcançaram as expectativas de aprendizagem para a etapa.

No caso da alfabetização, as referências originadas dos discursos feitos pelo Ministério da Educação em 2016 (por exemplo, o painel do Observatório do Plano Nacional de Educação) apresentam dados de monitoramento das metas do Plano Nacional de Educação (PNE), no ano de 2016, com o seguinte diagnóstico: 45,3\% dos estudantes com aprendizagem adequada em Leitura, 66,1\% dos estudantes com aprendizagem adequada em Escrita, e 45,5\% dos estudantes com aprendizagem adequada em Matemática. As informações foram calculadas com base nos dados da Avaliação Nacional da Alfabetização, publicados pelo Instituto Nacional de Estudos e Pesquisas Educacionais Anísio Teixeira (Inep). Segundo o Observatório:

Os alunos são divididos em quatro níveis de acordo com o desempenho obtido na ANA de Leitura, sendo que os dois últimos, nos quais são agrupados os estudantes com as maiores notas, são considerados como suficientes para constatar a alfabetização em Leitura dessas crianças. O resultado da avaliação em 2016 indicou que 45,3\% das crianças possuíam nível suficiente de Leitura. Esse percentual é a soma dos 32,3\% no nível 3 e dos 13\% no nível 4. Por outro lado, a maioria dos alunos terminavam o $3^{\circ}$ ano do Ensino Fundamental sem saber ler adequadamente: 21,7\% estavam no nível 1 e 33\% no nível 2 de proficiência. (Observatório do PNE, 2016b).

\section{$[\ldots]$}

O resultado da avaliação em 2016 indicou que 66,1\% das crianças possuíam nível suficiente de Escrita. Esse percentual é a soma dos 57,9\% no nível 4 e dos 8,3\% no nível 5. Por outro lado, os alunos que terminaram o $3^{\circ}$ ano do Ensino Fundamental sem saber escrever adequadamente somavam 33,9\%: 14,5\% estavam no nível 1, 17,2\% no nível 2 e 2,2\% no terceiro nível de proficiência.

Devido a mudanças metodológicas na ANA de Escrita, os anos de 2014 (primeira edição da prova) e 2016 (edição mais atual) não são comparáveis. (Observatório do PNE, 2016a).

9 A Anresc corresponde à parte censitária da avaliação, enquanto a Aneb constitui a parte amostral do Saeb. 
O resultado da avaliação em 2016 indicou que 45,5\% das crianças possuíam nível suficiente de alfabetização em Matemática. Esse percentual é a soma dos 18,4\% no nível 3 e dos $27,1 \%$ no nível 4 . Por outro lado, os alunos que terminaram o $3^{\circ}$ ano do Ensino Fundamental sem saber os números e algumas operações básicas adequadamente somavam 54,5\%: 23\% estavam no nível 1 e 31,5\% no nível 2 de proficiência. (Observatório do PNE, 2016c).

Divididas em quatro níveis diferentes, as escalas de Leitura e Matemática estão organizadas de maneira cumulativa e crescente, sendo o primeiro o nível mais baixo e o último aquele em que os estudantes adquirem as habilidades mais complexas. A escala de Escrita segue a mesma lógica, porém está organizada em cinco níveis diferentes. Nota-se que o Observatório do PNE considera que não atingiram a expectativa de aprendizagem os estudantes alocados nos dois primeiros níveis das escalas de Leitura e Matemática e nos três primeiros níveis da escala de Escrita ${ }^{10}$.

As escalas de proficiência em Leitura, Escrita e Matemática foram elaboradas pelo método bookmark, de acordo com nota explicativa do ano de 2013. Segundo ela, por esse método:

[...] os itens são organizados pelo grau de dificuldade, do mais fácil ao mais difícil, utilizando-se o parâmetro de dificuldade do modelo de resposta gradual e, em seguida, são demarcados os pontos em que ocorrem as mudanças de níveis de desempenho (Brasil. Inep, 2013b, p. 4).

A apresentação das escalas, portanto, produziu um agrupamento dos itens em níveis de proficiência que representavam melhor o desempenho dos estudantes nele alocados, resultando no formato da escala até hoje utilizada na avaliação da alfabetização ${ }^{11}$.

Para definir o nível adequado de alfabetização dos estudantes matriculados no $3^{\circ}$ ano do ensino fundamental foi necessário julgar, com base na interpretação pedagógica de cada nível das escalas, quais seriam suas habilidades e competências esperadas. Essa definição é fundamental para o monitoramento da Meta 5 do PNE, que prevê que todas as crianças estejam alfabetizadas até o final do $3^{\circ}$ ano.

O Observatório do PNE não apresenta a fundamentação teórica para escolha do ponto de corte utilizado e adota a definição divulgada no ano de 2017 sobre adequação da aprendizagem. No caso de Escrita e Matemática, observa-se uma concordância entre os referenciais curriculares e os pontos de corte apresentados. Na área de Leitura, a definição do terceiro nível da escala como aquele que melhor representa a expectativa

\footnotetext{
${ }^{10}$ Detalhes sobre a interpretação pedagógica e as habilidades mensuradas em cada um dos níveis das escalas de proficiência de Leitura, Escrita e Matemática da ANA podem ser conferidos nos Anexos A, B e C.

${ }^{11}$ O formato da escala, dividida em níveis, mantém-se o mesmo desde a edição de 2013. Contudo, a escala de Escrita foi refeita a cada edição, resultando em intervalos distintos a cada uma das divulgações de resultados.
} 
de aprendizagem dos estudantes nessa etapa não apresenta coerência em relação aos referenciais curriculares.

O Observatório acompanhou a definição de adequação proposta pelo Ministério da Educação na divulgação de resultados de 2017. Contudo, não havia material teórico, nota técnica ou qualquer outro documento oficial que justificasse essa delimitação. As análises teóricas, por outro lado, demonstram que o nível 2 corresponde ao conceito de alfabetização e letramento estabelecido nos documentos curriculares oficiais à época. Citam-se, abaixo, dois trechos importantes que justificam essa delimitação:

[...] compreensão atual da relação entre a aquisição das capacidades de redigir e grafar rompe com a crença arraigada de que o domínio do bê-á-bá seja pré-requisito para o início do ensino de língua e nos mostra que esses dois processos de aprendizagem podem e devem ocorrer de forma simultânea (Brasil. MEC, 2001, p. 33).

Nos dois primeiros anos do Ensino Fundamental, a ação pedagógica deve ter como foco a alfabetização, a fim de garantir amplas oportunidades para que os alunos se apropriem do sistema de escrita alfabética de modo articulado ao desenvolvimento de outras habilidades de leitura e de escrita e ao seu envolvimento em práticas diversificadas de letramentos (Brasil. MEC, 2017, p. 59).

Compreende-se que o nível 2 da escala de Leitura concentra as habilidades de consolidação do processo de alfabetização, pois os estudantes provavelmente conseguem utilizar as estratégias básicas de leitura para a compreensão de textos, tais como localizar informações explícitas, reconhecer a finalidade, identificar assunto e inferir relação de causa e consequência.

Essa posição é ratificada em carta aberta assinada pelas universidades que participaram do Pnaic.

São propostos quatro níveis de leitura. O primeiro nível é composto tanto por estudantes que não conseguem ler palavras, quanto pelos que conseguem ler palavras, mas não conseguem ler textos. A junção desses dois perfis em um só nível dificulta o debate sobre o diagnóstico feito, pois tradicionalmente as crianças que sabem ler e escrever palavras são consideradas alfabetizadas. Assim, em uma perspectiva tradicional no nível 1 estariam as crianças não alfabetizadas e as alfabetizadas. Muitas propostas de alfabetização, sobretudo centradas na memorização de letras, fonemas e sílabas apresentam tal concepção. No entanto, no PNAIC, é utilizada uma concepção de alfabetização que só considera a criança alfabetizada quando ela é capaz de ler textos. Desse modo, no PNAIC teríamos como nível mínimo esperado o nível 2, em que as crianças são capazes de ler textos curtos, identificando informações e reconhecendo as finalidades dos textos. Assim, 75,87\% poderiam ser consideradas alfabetizadas em 2013 e 77,79\% em 2014. (Ceale, 2015). 
Para este estudo foram utilizados os resultados das avaliações de Leitura e Matemática da ANA de 2016, tomando como referência os critérios técnicos acima descritos. Dessa forma, considerou-se que os estudantes definidos como alfabetizados em Leitura deveriam alcançar, minimamente, a proficiência equivalente ao nível 2, sendo os estudantes com proficiência de nível 1 considerados com desempenho insuficiente. Já para a área de Matemática, os estudantes com proficiência de nível 1 ou de nível 2 foram considerados com desempenho insuficiente, enquanto aqueles que atingiram o nível 3 foram classificados como "suficiente". Além disso, os alunos que atingiram o nível 4 das escalas de proficiência foram classificados na categoria “desejável”, tanto para a área de Leitura quanto para Matemática.

\section{QUADRO 1}

CLASSIFICAÇÃO DOS NÍVEIS DAS ESCALAS DE LEITURA E MATEMÁTICA DA ANA A PARTIR DAS COMPETÊNCIAS E HABILIDADES ESPERADAS PARA O $3^{\circ}$ ANO DO ENSINO FUNDAMENTAL

\begin{tabular}{|c|c|c|c|}
\hline \multicolumn{2}{|c|}{ ESCALAS } & LEITURA & MATEMÁTICA \\
\hline \multirow{4}{*}{ NÍVEIS } & 1 & INSUFICIENTE & INSUFICIENTE \\
\hline & 2 & SUFICIENTE & INSUFICIENTE \\
\hline & 3 & SUFICIENTE & SUFICIENTE \\
\hline & 4 & DESEJÁVEL & DESEJÁVEL \\
\hline
\end{tabular}

Fonte: Elaboração própria.

Para que este texto pudesse cumprir sua função de suscitar o debate sobre as influências diversas nos processos de ensino aprendizagem e apoiar efetivamente a formulação de políticas públicas na área, foi necessário assumir uma classificação que considerasse as expectativas de aprendizagem nos resultados das avaliações de larga escala. Dessa forma, optou-se por adotar um conceito de alfabetização amplamente difundido e que também se reflete na própria concepção da avaliação.

Educar, no sentido de alcançar tais objetivos de alfabetização e letramento, visa garantir que as crianças possam vivenciar, desde cedo, atividades que as levem a pensar sobre as características do nosso sistema de escrita, de forma reflexiva, lúdica, inseridas em atividades de leitura e escrita de diferentes textos. É importante considerar, no entanto, que a apropriação da escrita alfabética não significa que o sujeito esteja alfabetizado. Essa é uma aprendizagem fundamental, mas, para que os indivíduos possam ler e produzir textos com autonomia, é necessário que eles consolidem as correspondências grafofônicas, ao mesmo tempo que vivenciem atividades de leitura e produção de textos (Brasil. MEC, 2012, apud Brasil. Inep, 2013a, p. 10).

Nesse sentido, para fins de classificação do nível de alfabetização esperado pelo Plano Nacional de Educação, e tomando por referência a avaliação aplicada nos 
últimos anos, considera-se alfabetizado o estudante que desempenha habilidades além da mera decodificação, sendo capaz de interpretar textos e operacionalizar uma leitura mais qualificada em relação à mera leitura de palavras. No caso de Matemática, da mesma forma, buscou-se nos referenciais curriculares as expectativas de aprendizagem declaradas para a etapa de ensino e adotou-se a nomenclatura de "insuficiência” ou "não alfabetizado" estritamente no recorte dessa avaliação.

\section{CENÁRIO NACIONAL NA AVALIAÇÃO NACIONAL DA ALFABETIZAÇÃO NO ANO DE 2016}

As análises apresentadas tomaram como referência a definição de alfabetização discutida na seção anterior, em concordância com vários especialistas da área e com as equipes pedagógicas da Diretoria de Avaliação da Educação Básica (Daeb) do Inep.

É comum, como se verifica na apresentação dos padrões por outras entidades, que a expectativa de aprendizagem se coloque em termos de adequação e suficiência e que os níveis acima dessa expectativa se tornem desejáveis, uma vez que quanto maior a aquisição de habilidade, melhor preparado o indivíduo estaria para seguir com a sua trajetória escolar.

Do ponto de vista metodológico, nesse primeiro momento, optou-se por uma análise exploratória geral dos dados levantados a partir da ANA. O objetivo dessa análise descritiva é traçar um panorama geral da alfabetização em Leitura e em Matemática no Brasil, trazendo resultados gerais e agregados por regiões geográficas, unidades da Federação, rede, localização e município.

Considerando o cenário nacional, nota-se, a partir do Gráfico 1, que pouco mais de $20 \%$ dos estudantes matriculados em turmas regulares em 2016 não possuíam habilidades elementares em Leitura, ou seja, dominavam a leitura de palavras isoladas, mas não estavam qualificados para o domínio da leitura de textos. Para a área de Matemática, nota-se que mais da metade da população avaliada (54\%) não adquiriu as habilidades básicas nessa área. Isso significa dizer que, provavelmente, esses estudantes não estariam aptos sequer a criar uma correspondência de valor monetário a cédulas de igual valor.

A insuficiência de aprendizagem, que aparentemente afeta mais a área de Matemática, pode se estabelecer por meio da formação de professores ou mesmo pela necessidade sentida pelas escolas, sobretudo as de baixo nível socioeconômico, de centrar seus esforços na aquisição das habilidades de Leitura e Escrita. Esse cenário pode estar ainda mais visível a partir da publicação da BNCC, que prioriza a aquisição de Leitura e Escrita nos dois primeiros anos de escolarização, e do consequente PNA, que pouca atenção dá à área de Matemática. 


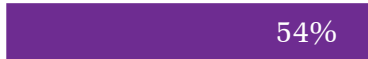

$18 \%$

$27 \%$

Insuficiente $\quad$ Suficiente $\quad$ Desejável

\section{GRÁFICO 1}

\section{PERCENTUAL DE ESTUDANTES EM CADA NIVEL DE ALFABETIZAÇÃO EM LEITURA E MATEMÁTICA PARA O $3^{\circ}$ ANO DO ENSINO FUNDAMENTAL - BRASIL - 2016}

Fonte: Elaboração própria com base em microdados da ANA (Brasil. Inep, 2016b).

Os resultados de alfabetização, agregados por região geográfica, podem ser conferidos no Gráfico 2. Observa-se que as regiões Norte e Nordeste possuem um quadro mais preocupante em relação à alfabetização. Para a área de Leitura, o percentual de crianças matriculadas no $3^{\circ}$ ano que não alcançaram o nível de alfabetização esperado fica próximo de 35\%. Já para a área de Matemática, esse percentual atingiu cerca de $70 \%$ dos estudantes. As regiões Sul e Sudeste apresentaram um cenário mais positivo, com percentual de estudantes com desempenho insuficiente em Leitura e Matemática inferior a 15\% e 45\%, respectivamente. O Centro-Oeste possui situação intermediária e seus percentuais ficam um pouco abaixo dos resultados nacionais.

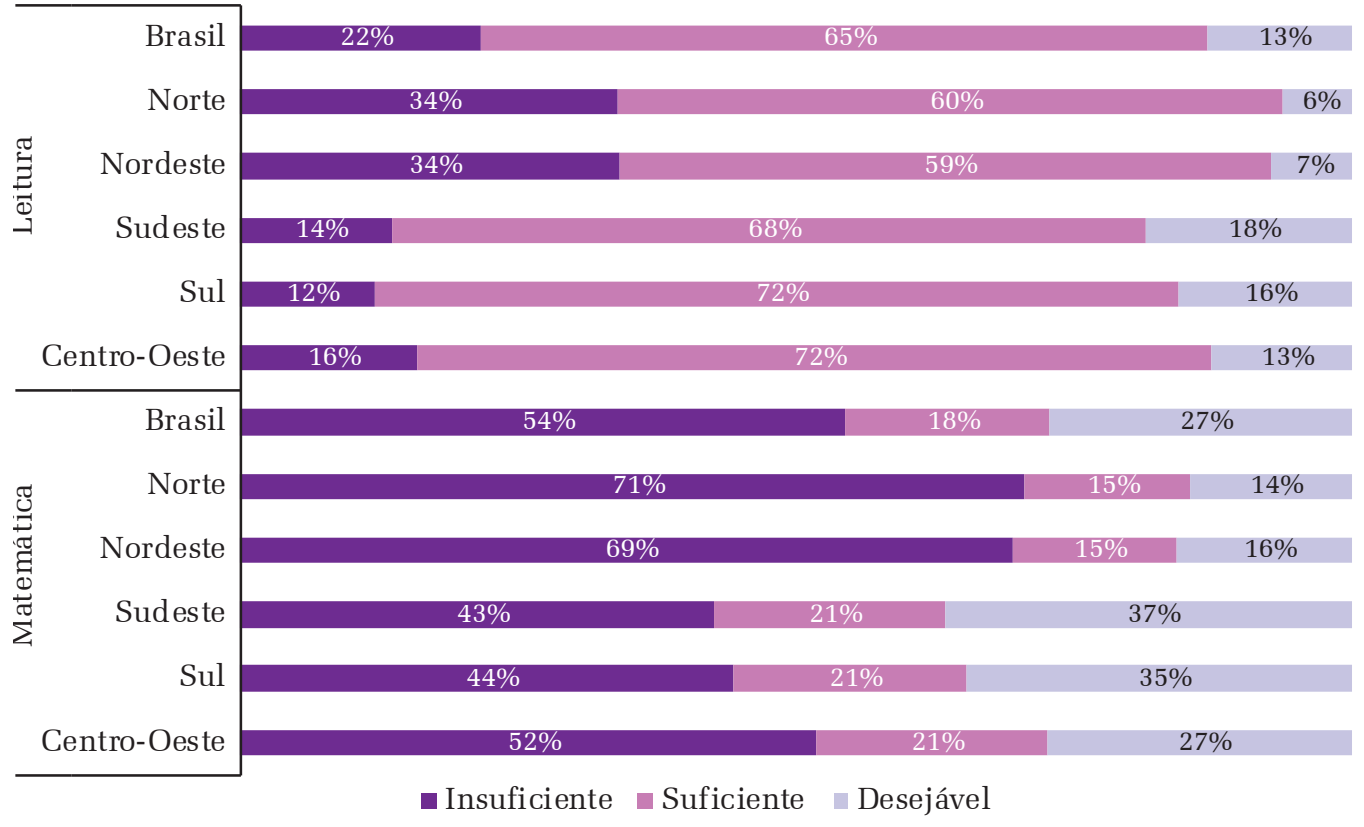

GRÁFICO 2

\section{PERCENTUAL DE ESTUDANTES EM CADA NÍVEL DE ALFABETIZAÇÃO EM LEITURA E MATEMÁTICA PARA O $3^{\circ}$ ANO DO ENSINO FUNDAMENTAL - BRASIL E REGIÕES - 2016}

Fonte: Elaboração própria com base em microdados da ANA (Brasil. Inep, 2016b). 
Em relação ao nível de proficiência desejável, destacam-se os resultados do Sul e do Sudeste, regiões com os maiores percentuais de estudantes nesse nível nas duas áreas. Nota-se que a região Centro-Oeste apresentou resultados equivalentes aos nacionais, enquanto as regiões Norte e Nordeste apresentaram menor percentual de estudantes com desempenho desejável.

Comparando os resultados de alfabetização agregados por zona urbana ou rural, observa-se no Gráfico 3 que os padrões de desempenho são melhores nas escolas de zonas urbanas em ambos os componentes curriculares. Em Leitura, o percentual de estudantes considerados abaixo da expectativa de aprendizagem para a etapa foi de $20 \%$ na zona urbana e de 35\% na zona rural. Para Matemática, 52\% dos estudantes da área urbana apresentaram desempenho insuficiente, enquanto na área rural esse percentual atingiu quase $70 \%$.

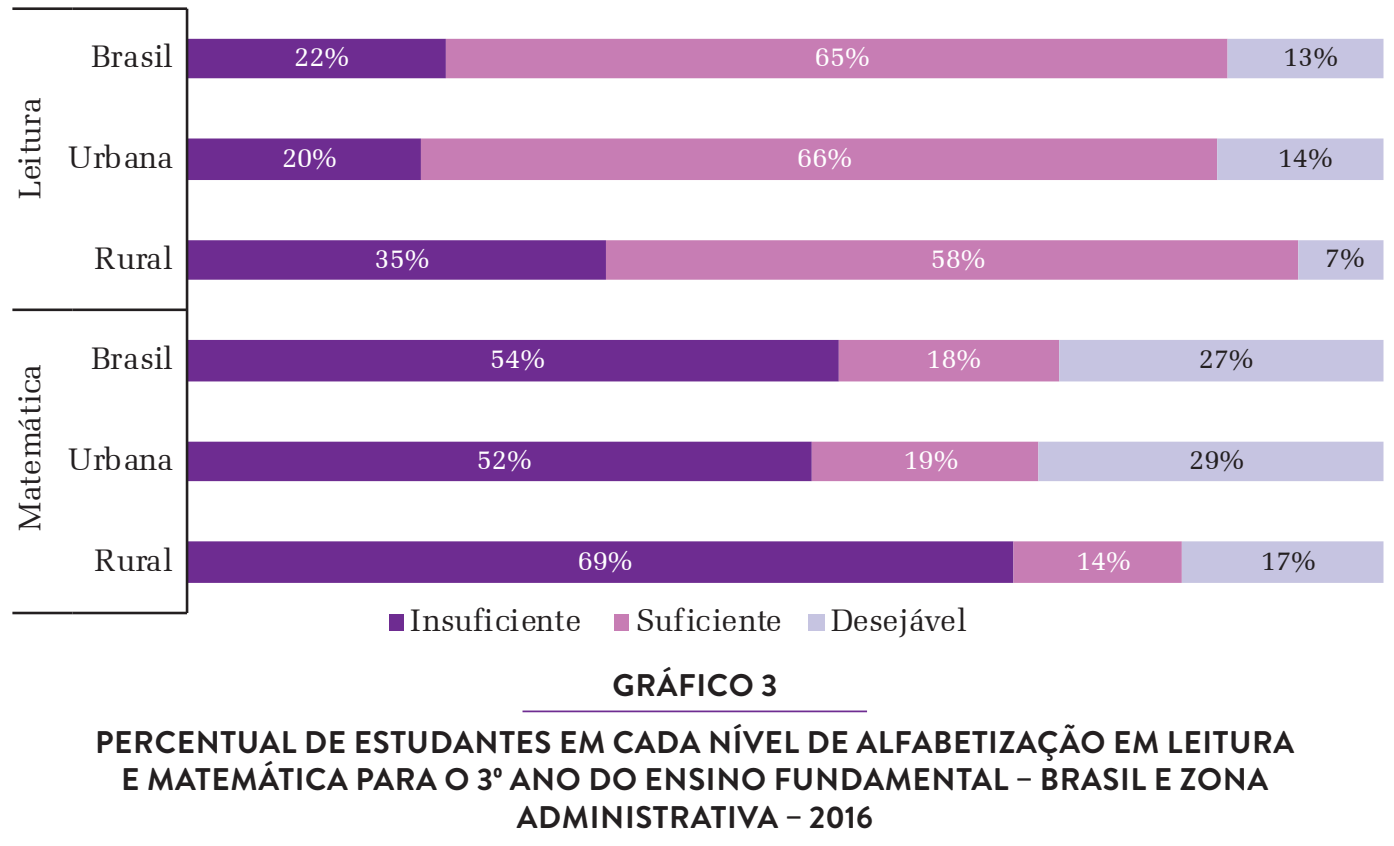

Fonte: Elaboração própria com base em microdados da ANA (Brasil. Inep, 2016b).

Quanto às redes, embora os resultados apresentados no Gráfico 4 demonstrem uma qualidade superior no desempenho da rede federal, é necessário relativizar essa informação dada a quantidade de matrículas apenas residual nessa rede. A rede municipal apresentou o maior percentual de alunos com desempenho abaixo do esperado para essa etapa nas duas áreas, sendo também a rede com o maior número de matrículas ${ }^{12}$.

\footnotetext{
${ }^{12}$ Em relação aos estudantes avaliados na ANA 2016 temos que: 82,30\% estavam matriculados em escola da rede municipal, 17,64 \% em escolas da rede estadual e apenas $0,05 \%$ pertencia à rede federal de ensino.
} 


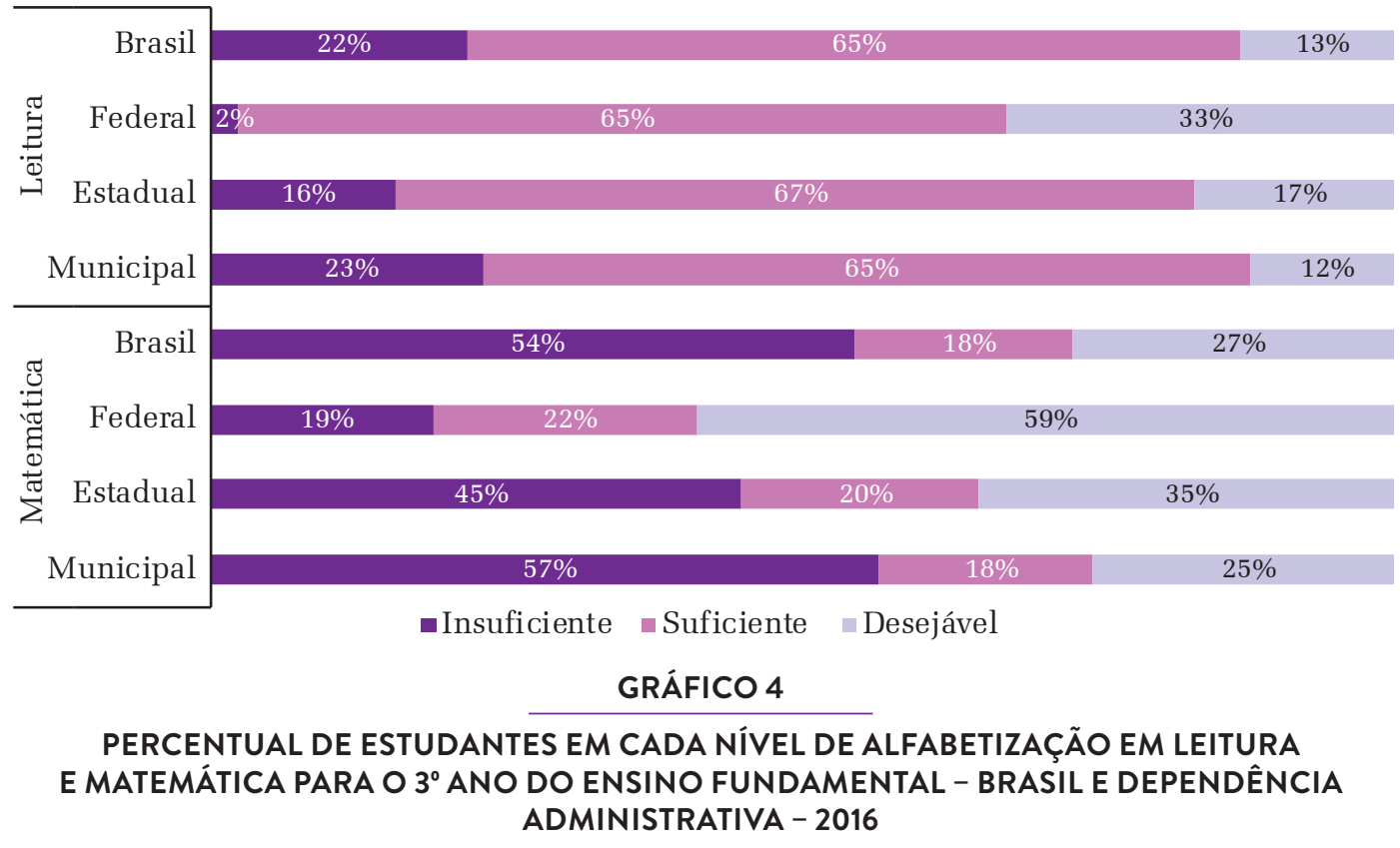

Fonte: Elaboração própria com base em microdados da ANA (Brasil. Inep, 2016b).

Os próximos gráficos trazem um panorama da alfabetização por região geográfica, sendo os resultados agregados por unidade da Federação. Começando com a região Norte é possível notar a partir do Gráfico 5 que os estados do Amapá e do Pará são os que possuem a maior proporção de crianças que não apresentaram níveis satisfatórios nas avaliações de Leitura e de Matemática. No Amapá, por exemplo, o percentual de estudantes com desempenho insuficiente em Leitura é mais do que o dobro do resultado nacional (45\% contra 22\%), enquanto em Matemática os alunos apresentaram resultados ainda mais preocupantes, com cerca de $80 \%$ das crianças com desempenho abaixo do esperado. Nessa região, apenas os estados do Acre e de Rondônia tiveram resultados compatíveis com os índices nacionais. O percentual de estudantes com desempenho abaixo do esperado em Leitura no Acre foi de $17 \%$ e em Rondônia de 22\%. Já para a área de Matemática, 53\% dos estudantes do Acre não conseguiram atingir o nível suficiente, enquanto em Rondônia esse percentual foi um pouco maior, de 59\%.

Em relação ao percentual de estudantes com desempenho desejável, nota-se que nenhum estado do Norte superou o índice nacional, mas é importante mencionar que o Acre apresentou resultados bem próximos ao agregado Brasil. 
$\mathrm{Na}$ região Nordeste, os estados que apresentaram maior concentração de estudantes com desempenho insuficiente em Leitura foram: Sergipe (45\%), seguido por Alagoas (43\%) e pelo Maranhão (40\%). O Ceará, por sua vez, apresentou o cenário mais positivo da região, tendo cerca de $15 \%$ de seus estudantes com desempenho insuficiente em Leitura, índice abaixo do nacional (22\%).

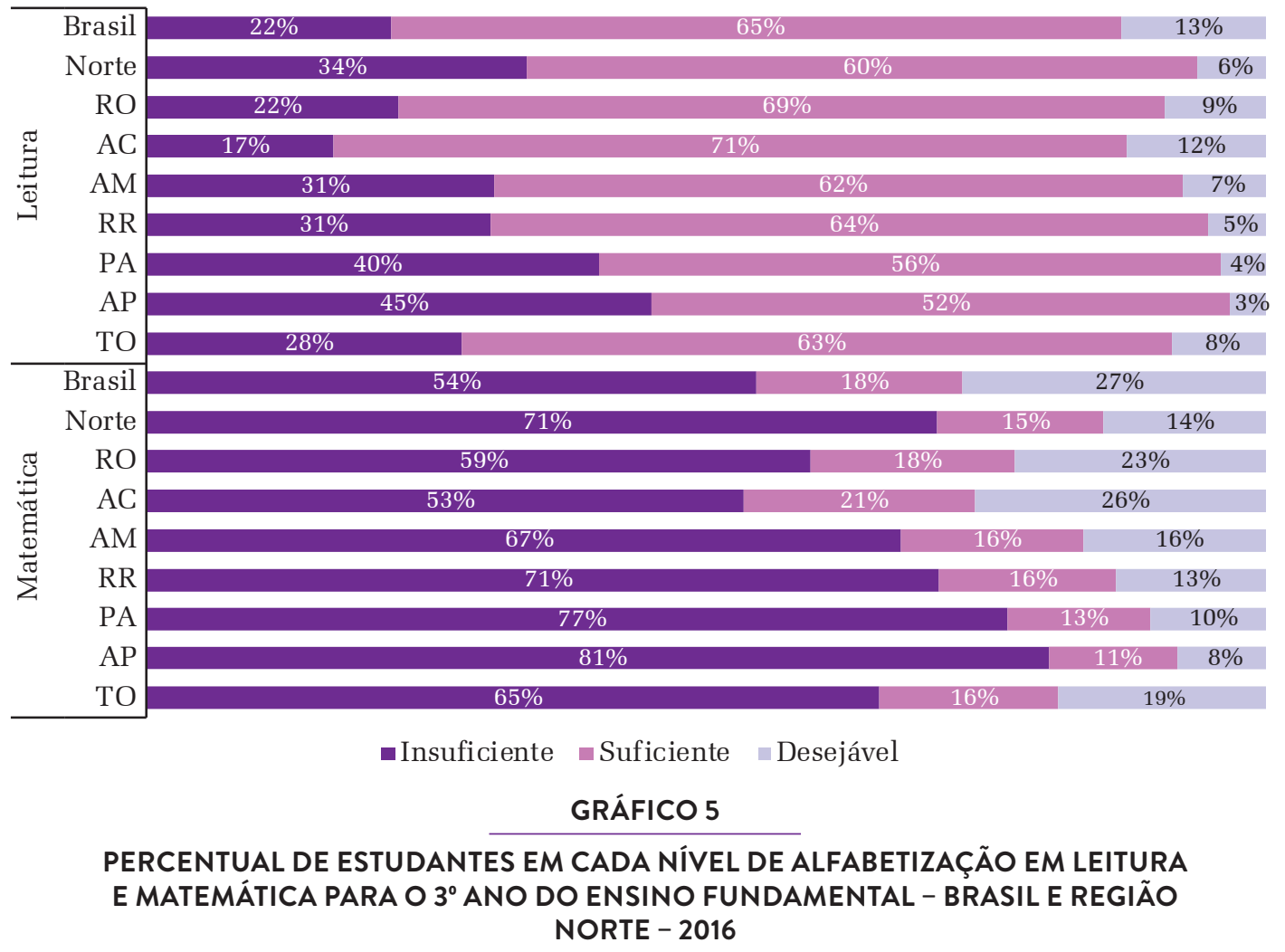

Fonte: Elaboração própria com base em microdados da ANA (Brasil. Inep, 2016b).

Na área de Matemática, o estado do Sergipe também apresentou a maior concentração de estudantes no nível mais baixos da escala (80\%), seguido pelos estados do Maranhão e de Alagoas, onde mais de 75\% das crianças tiveram resultados insuficientes. O Ceará aparece novamente como destaque positivo da região Nordeste. Apesar de 48\% das crianças terem resultados abaixo do esperado em Matemática, esse percentual foi bem inferior ao resultado global da região Nordeste (69\%) e do resultado nacional (54\%).

Importante destacar que o Ceará, além de apresentar um percentual de estudantes abaixo da expectativa de aprendizagem nas duas áreas menor que os resultados nacionais, também apresentou um percentual maior de estudantes com desempenho desejável nas duas áreas, se comparado aos resultados nacionais. 


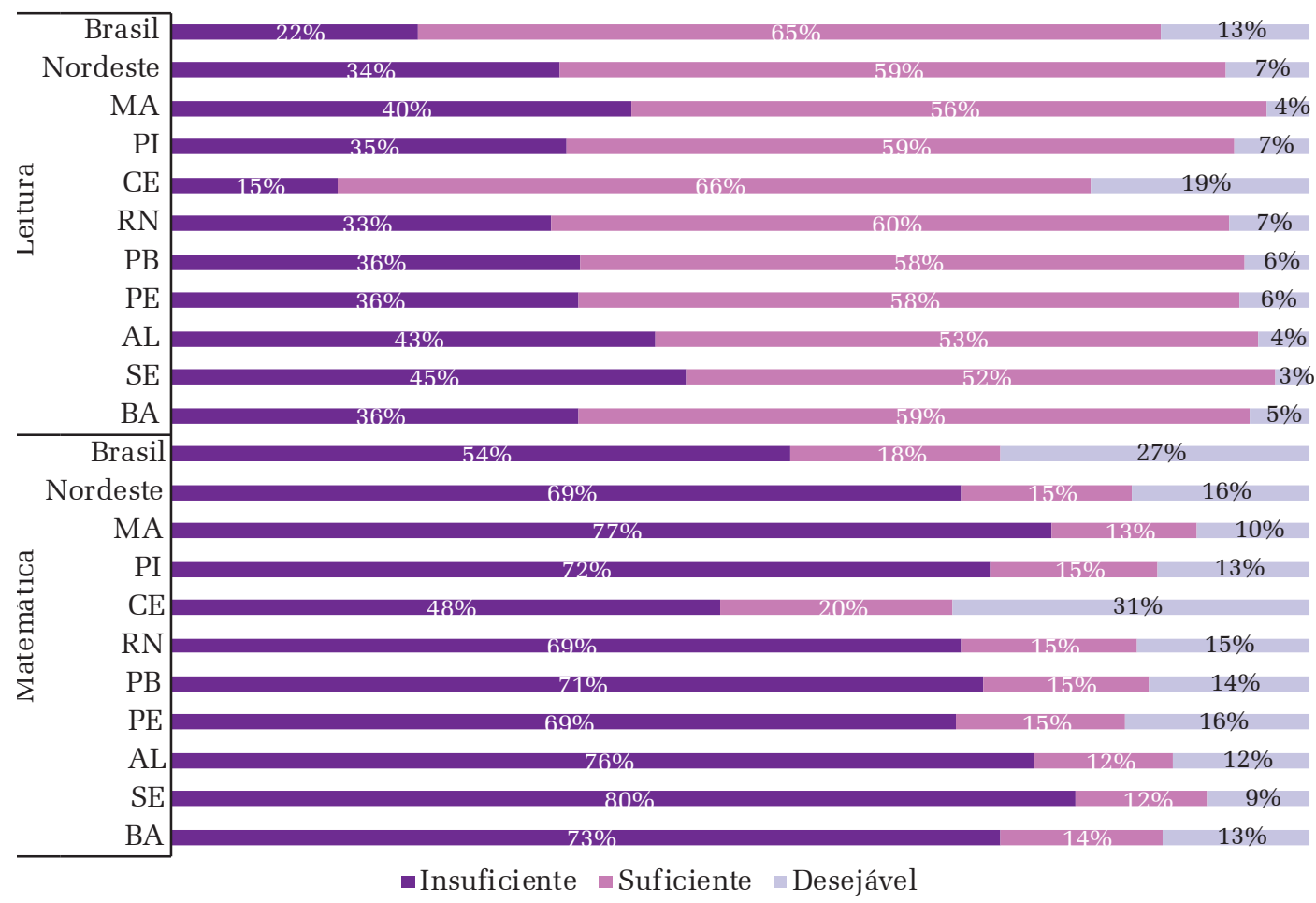

GRÁFICO 6

PERCENTUAL DE ESTUDANTES EM CADA NÍVEL DE ALFABETIZAÇÃO EM LEITURA E MATEMÁTICA PARA O $3^{\circ}$ ANO DO ENSINO FUNDAMENTAL - BRASIL E REGIÃO NORDESTE - 2016

Fonte: Elaboração própria com base em microdados da ANA (Brasil. Inep, 2016b).

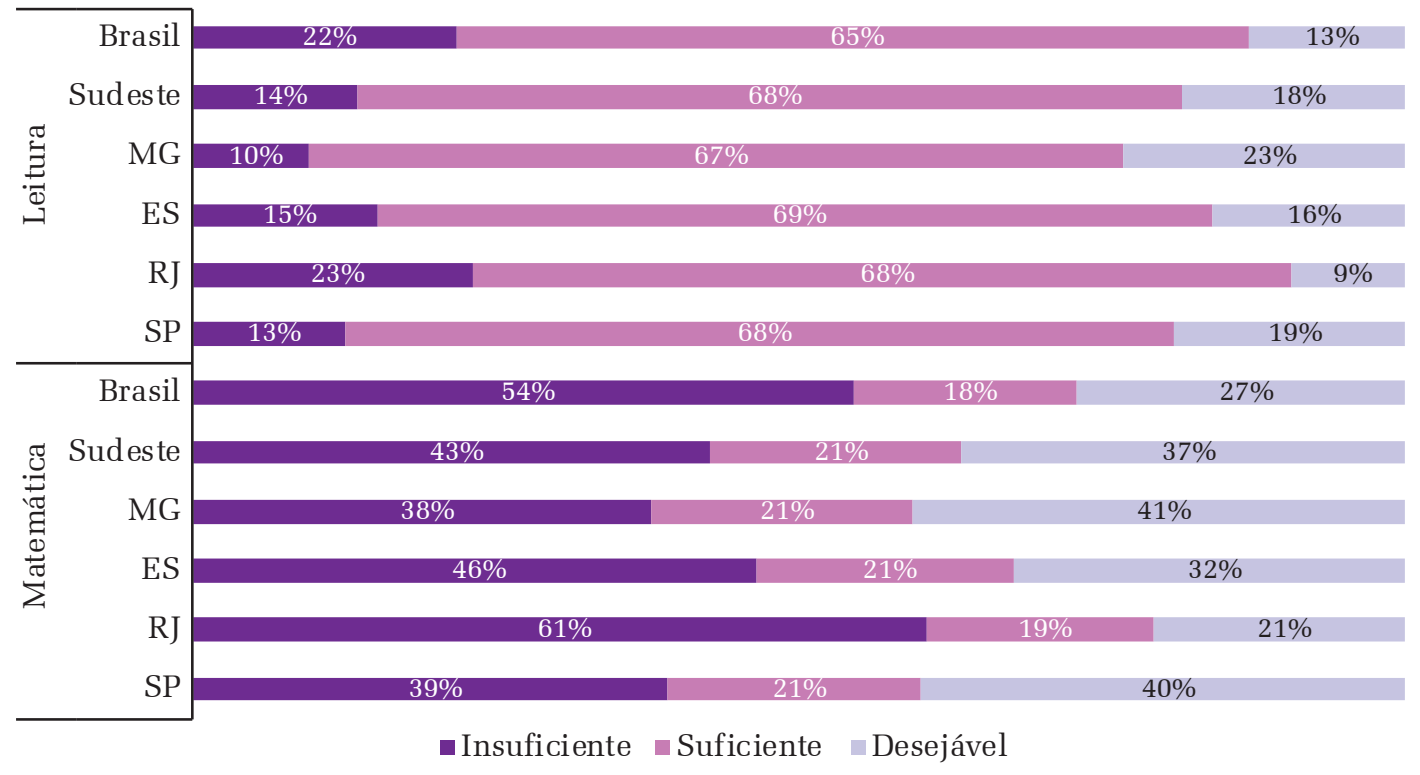

GRÁFICO 7

PERCENTUAL DE ESTUDANTES EM CADA NÍVEL DE ALFABETIZAÇÃO EM LEITURA E MATEMÁTICA PARA $O 3^{\circ}$ ANO DO ENSINO FUNDAMENTAL - BRASIL E REGIÃO SUDESTE - 2016

Fonte: Elaboração própria com base em microdados da ANA (Brasil. Inep, 2016b) 
O Gráfico 7 retrata o panorama da alfabetização para a região Sudeste. Em geral, os estados dessa região apresentaram desempenhos superiores à média nacional. O Rio de Janeiro é o único estado na região que apresentou resultados piores que o nacional, tendo $23 \%$ dos estudantes alocados no nível insuficiente em Leitura e 61\% em Matemática. Minas Gerais foi o estado do Sudeste que apresentou os melhores resultados quanto à alfabetização, com apenas 10\% de seus estudantes com desempenho insuficiente em Leitura e 38\% em Matemática, seguido de perto por São Paulo, com índices em 13\% e 39\%, respectivamente. Além disso, todos os estados da região, excluindo o Rio de Janeiro, apresentaram maior percentual de estudantes com desempenho desejável nas duas áreas, quando comparados aos resultados nacionais.

Para a região Sul, o cenário da alfabetização é apresentado no Gráfico 8. Todos os estados dessa região apresentaram índices de alfabetização melhores que o nacional. Santa Catarina, o estado mais destacado na região, apresentou resultados compatíveis com os resultados de Minas Gerais nas duas áreas avaliadas. Já o Rio Grande do Sul, com maior percentual de estudantes nos níveis insuficientes na região Sul, tem resultados próximos aos do Ceará, estado de maior destaque no Nordeste. Em relação ao percentual de estudantes com desempenho desejável, nota-se que todos os estados da região Sul apresentaram índices maiores que os nacionais.

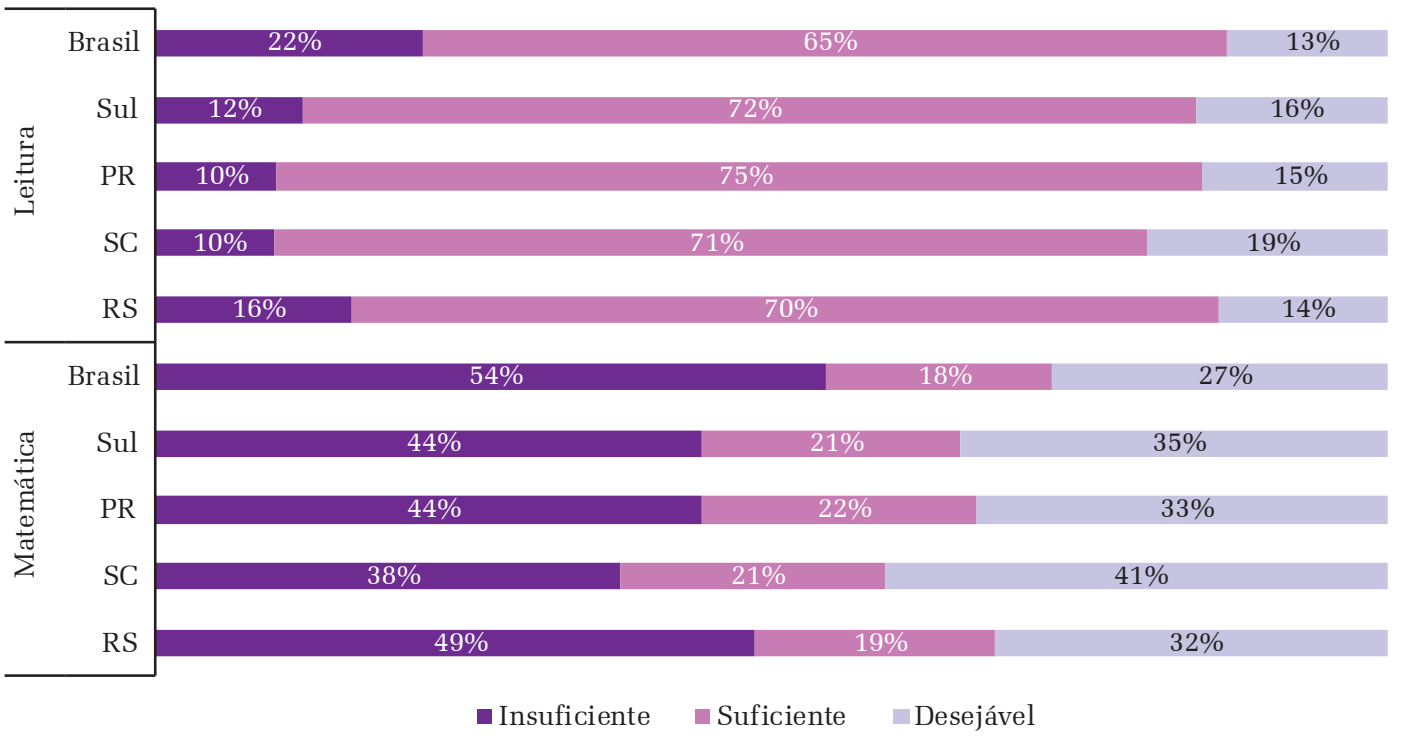

GRÁFICO 8

PERCENTUAL DE ESTUDANTES EM CADA NÍVEL DE ALFABETIZAÇÃO EM LEITURA E MATEMÁTICA PARA O $3^{\circ}$ ANO DO ENSINO FUNDAMENTAL - BRASIL E REGIÃO SUL - 2016

Fonte: Elaboração própria com base em microdados da ANA (Brasil. Inep, 2016b).

Por fim, o Gráfico 9 traz os resultados para a região Centro-Oeste. Para a área de Leitura, todos os estados apresentaram um percentual de estudantes com desempenho 
abaixo do esperado menor que o observado para o agregado Brasil. O Distrito Federal é o que apresentou menor percentual, cerca de $12 \%$, contra $22 \%$ do índice nacional. Na área de Matemática, todos os estados apresentaram um percentual muito próximo ao resultado nacional, em torno de 54\%. O Distrito Federal é o que mais se distancia positivamente do resultado nacional, tendo $43 \%$ dos estudantes com desempenho insuficiente.

Em relação à categoria mais elevada de aprendizagem, o Distrito Federal também foi o estado mais destacado da região Centro-Oeste, apresentando maiores percentuais de estudantes com proficiência desejável nas duas áreas avaliadas. Os demais estados dessa região apresentaram índices bem próximos ao agregado Brasil.

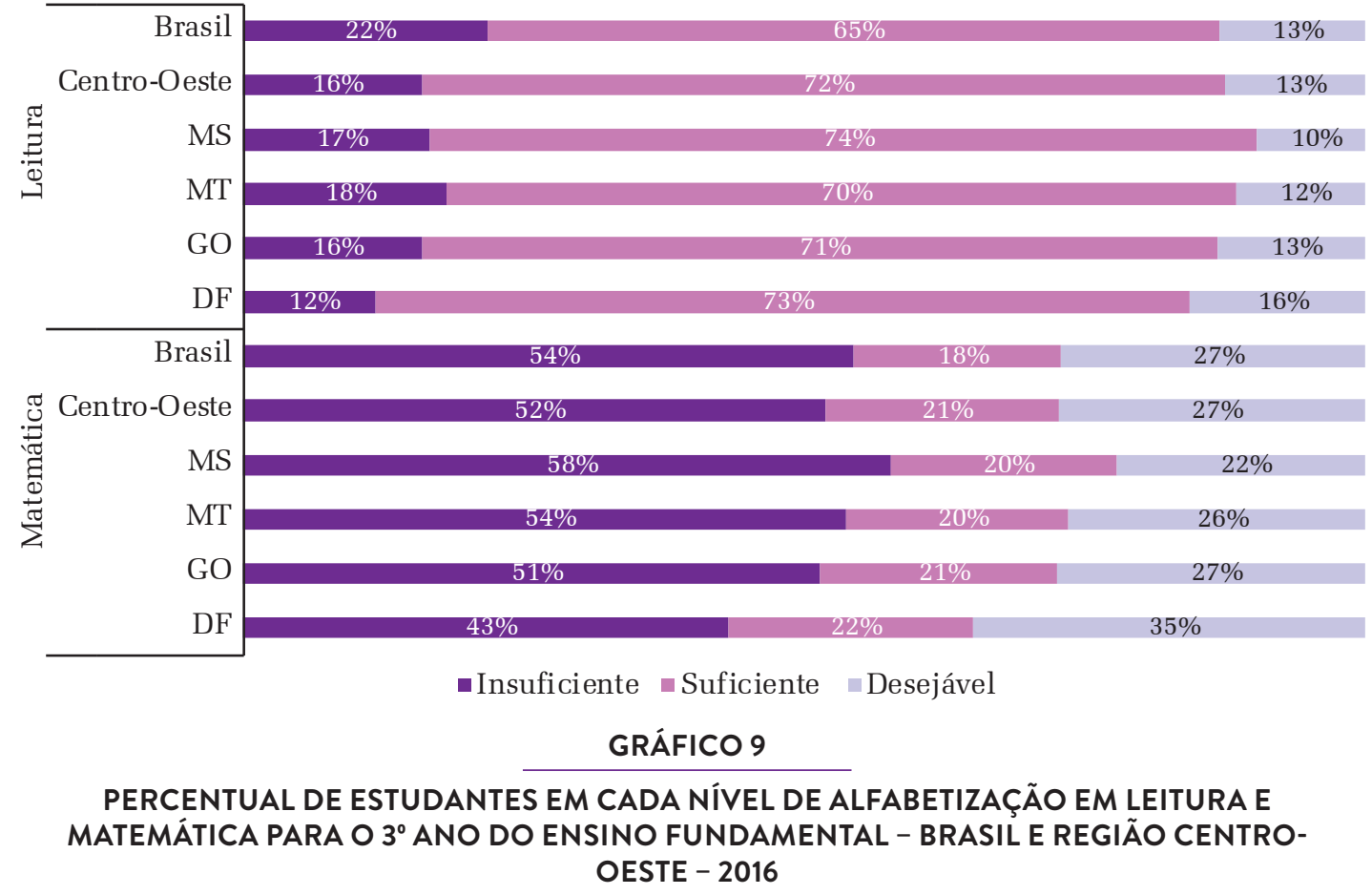

Fonte: Elaboração própria com base em microdados da ANA (Brasil. Inep, 2016b).

Os mapas apresentados na Figura 1 demonstram visualmente a concentração de estudantes com desempenho insuficiente (à esquerda) e desejável (à direita) na área de Leitura nos municípios brasileiros. As cores mais fortes indicam uma maior concentração. Verifica-se, de maneira geral, que as regiões Norte e Nordeste possuem uma elevada concentração de municípios com altos percentuais de estudantes com desempenho insuficiente. Apenas o Ceará e parte do Acre e de Rondônia apresentaram um cenário diferenciado em relação aos demais municípios dessas duas regiões. Quando se toma a expectativa de aprendizagem dos estudantes em relação ao desejável, ou seja, a superação dos níveis mais baixos da escala, observa-se que o percentual de estudantes com resultados desejáveis é maior para os municípios que compõem as regiões Sul e Sudeste e o estado do Ceará. 


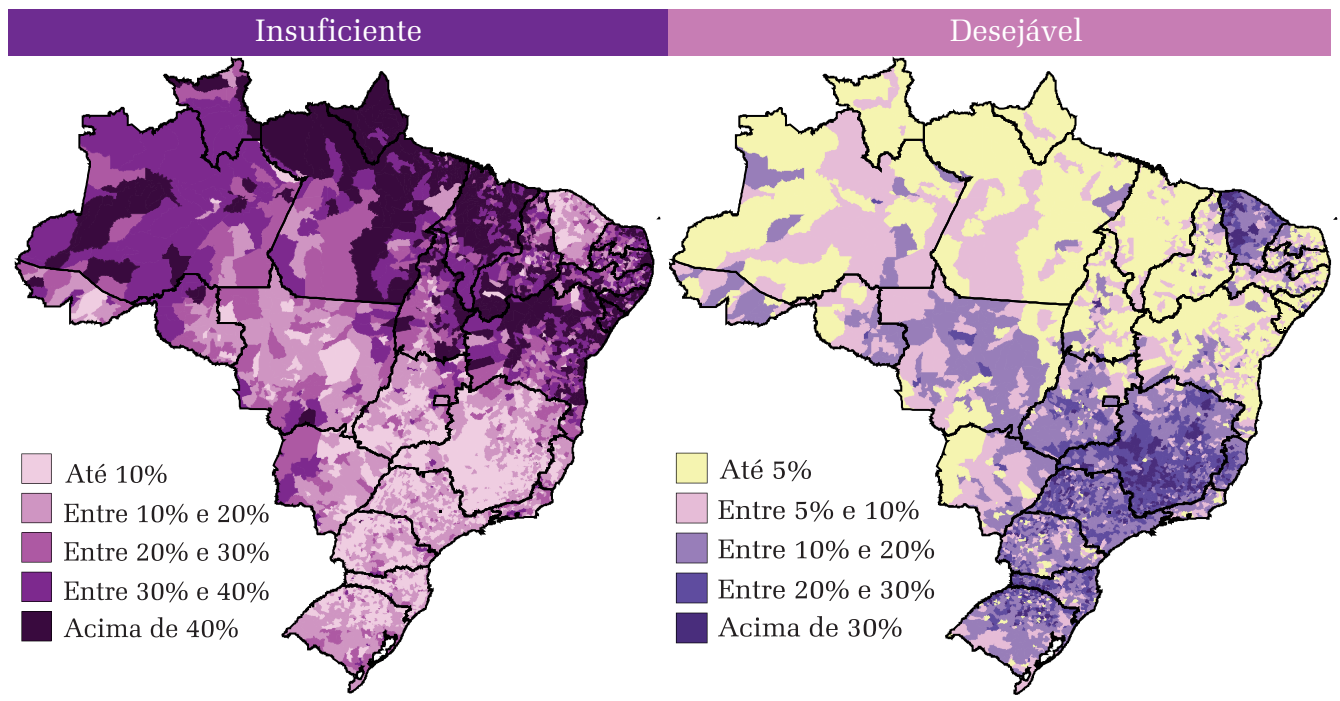

FIGURA 1

\section{PERCENTUAL DE ESTUDANTES COM NÍVEL DE ALFABETIZAÇÃO INSUFICIENTE E DESEJÁVEL EM LEITURA - BRASIL - 2016}

Fonte: Elaboração própria com base em microdados da ANA (Brasil. Inep, 2016b).

O cenário se repete no caso da área de Matemática, embora o desempenho global esteja aquém em relação à área de Leitura, conforme se observa nos mapas da Figura 2. Mais uma vez, destacam-se os municípios das regiões Sul e Sudeste e o estado do Ceará com menor percentual de estudantes do $3^{\circ}$ ano com desempenho insuficiente (à esquerda) e com maior percentual de estudantes com desempenho desejável (à direita).

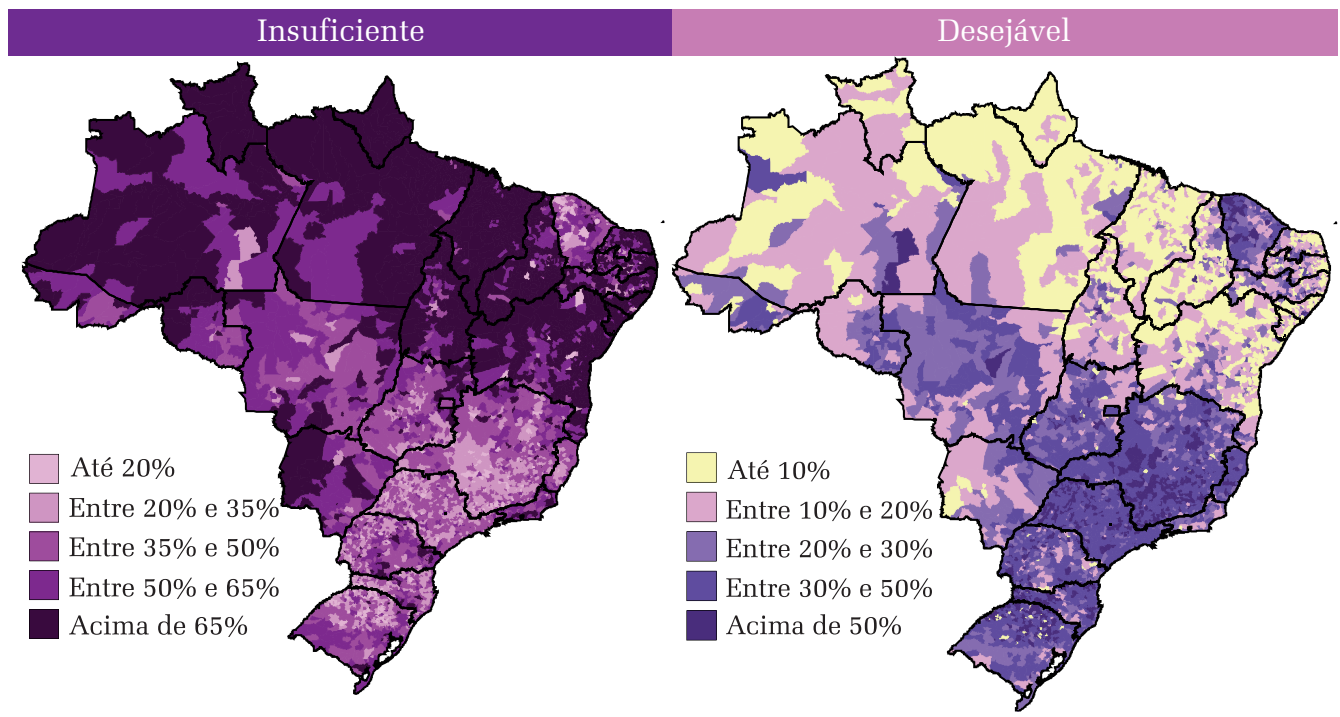

FIGURA 2

\section{PERCENTUAL DE ESTUDANTES COM NÍVEL DE ALFABETIZAÇÃO INSUFICIENTE E DESEJÁVEL EM MATEMÁTICA - BRASIL - 2016}


De maneira geral, os resultados sobre o panorama da alfabetização trazido nesta seção indicaram que o Brasil apresenta um percentual considerável de estudantes com desempenho abaixo do esperado, especialmente na área de Matemática, em que mais da metade dos alunos tiveram desempenho insuficiente para o $3^{\circ}$ ano. Esse cenário é ainda mais preocupante nas regiões Norte e Nordeste e na zona rural, onde a proporção de estudantes com baixo desempenho atingiu uma parcela considerável da população. É interessante destacar que o estado do Ceará apresentou resultados consideravelmente melhores do que o restante do Nordeste, sendo seus índices de alfabetização em Leitura e Matemática comparáveis aos índices observados para as regiões Sul e Sudeste. De todo modo, fica claro que serão necessários grandes esforços para se atingir a Meta 5 do PNE, que propõe que até 2024 todas as crianças sejam alfabetizadas até o $3^{\circ}$ ano do ensino fundamental.

\section{RELAÇÃO ENTRE ALFABETIZAÇÃO E INDICADORES DE CONTEXTO}

Nesta seção, são apresentadas algumas análises que visam retratar a relação existente entre os índices de alfabetização ${ }^{13}$ e alguns indicadores contextuais das escolas e dos municípios brasileiros. Para o nível escola, foram considerados dois indicadores: o nível socioeconômico da escola (Indicador de Nível Socioeconômico das Escolas de Educação Básica - Inse) ${ }^{14}$ e a Adequação da Formação Docente (AFD) ${ }^{15}$. O Inse retrata o status socioeconômico médio dos estudantes atendidos por uma dada instituição de ensino, enquanto a AFD mensura a proporção de docentes da escola com formação adequada para lecionar em determinada área e etapa de ensino. Para esse estudo, foram considerados como com formação adequada os professores pertencentes ao grupo $1^{16}$ e que atuavam nos anos iniciais do ensino fundamental.

\footnotetext{
${ }^{13}$ Os índices para descrever a situação da alfabetização nas escolas e nos municípios brasileiros foram: o percentual de estudantes do $3^{\circ}$ ano do ensino fundamental com desempenho insuficiente em Leitura e em Matemática e o percentual de estudantes com desempenho desejável nessas duas áreas.

${ }^{14}$ Detalhes sobre o Inse podem ser encontrados em: <http://download.inep.gov.br/informacoes estatisticas/indicadores_educacionais/2011_2013/nivel_socioeconomico/nota_tecnica_indicador_nivel_ socioeconomico.pdf $>$.

${ }^{15}$ Detalhes sobre AFD podem ser encontrados em: < http://download.inep.gov.br/informacoes_estatisticas/ indicadores_educacionais/2014/docente_formacao_legal/nota_tecnica_indicador_docente_formacao_ legal.pdf>.

${ }^{16} \mathrm{O}$ indicador de AFD é divido em cinco grupos, sendo que o grupo 1 (maior nível de adequação) é formado por docentes com licenciatura na mesma disciplina que lecionam ou bacharelado na mesma disciplina com curso de complementação pedagógica concluído.
} 


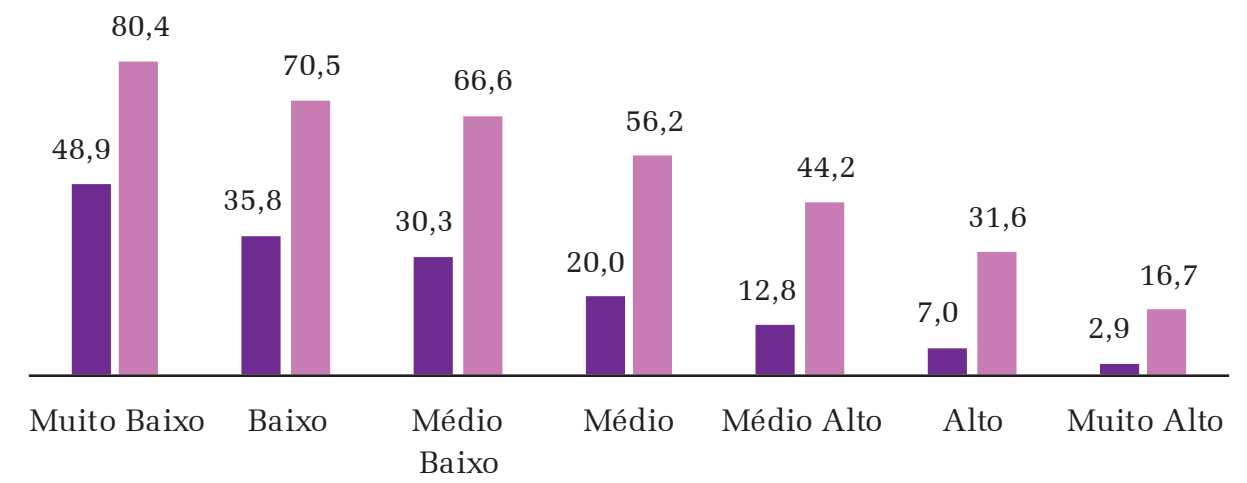

Percentual de estudantes com desempenho insuficiente em Leitura

Percentual de estudantes com desempenho insuficiente em Matemática

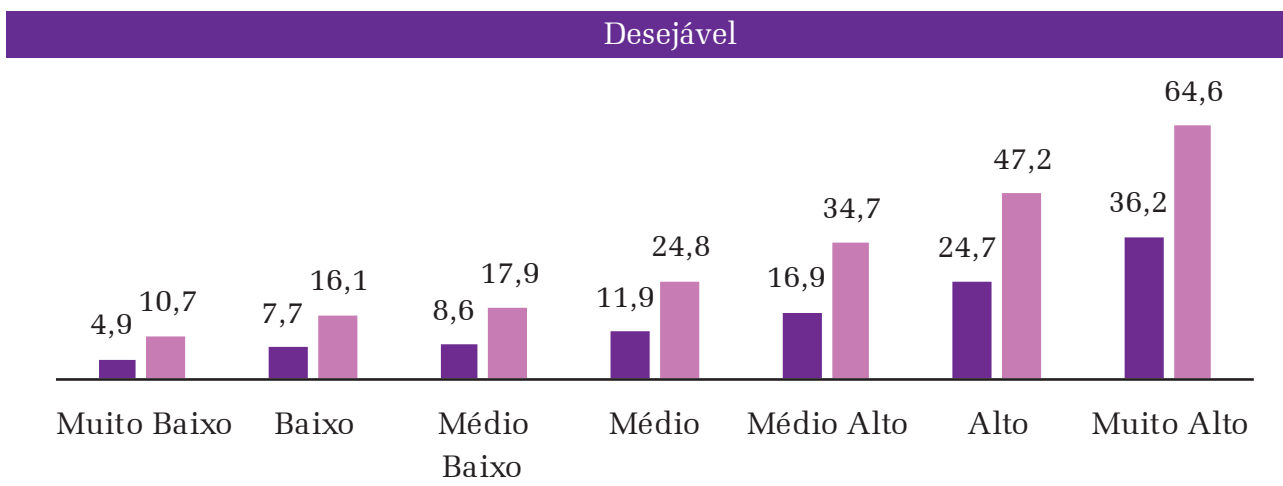

Percentual de estudantes com des empenho des ejável em Leitura

Percentual de estudantes com desempenho desejável em Matemática

FIGURA 3

\section{PERCENTUAL MÉDIO DE ESTUDANTES COM DESEMPENHO INSUFICIENTE E COM DESEMPENHO DESEJÁVEL, POR NIVVEL SOCIOECONÔMICO DA ESCOLA}

Fonte: Elaboração própria com base em microdados da ANA (Brasil. Inep, 2016b).

Na Figura 3, são apresentados dois gráficos que descrevem a relação entre o nível socioeconômico médio dos estudantes e os índices de alfabetização da escola. Os índices de alfabetização foram mensurados por instituição de ensino e representam no gráfico à esquerda o percentual de estudantes do $3^{\circ}$ ano do ensino fundamental com desempenho insuficiente e no gráfico à direita o percentual de estudantes com desempenho desejável. Essa análise contou com uma amostra de mais de 30 mil escolas que possuíam Inse calculado e que apresentaram taxa de participação na ANA de pelo menos $80 \%$ de seus estudantes do $3^{\circ}$ ano. O primeiro gráfico traz o valor médio do percentual de estudantes com desempenho insuficiente em Leitura e em Matemática 
para cada um dos grupos de nível socioeconômico das escolas. Os resultados indicam que quanto maior o nível socioeconômico da instituição, menor será o percentual de estudantes com desempenho abaixo do esperado nas duas áreas. O percentual médio de estudantes com desempenho insuficiente em Leitura entre as escolas de menor Inse ficou próximo de 50\%, enquanto as escolas de maior nível socioeconômico apresentaram um percentual próximo de 3\%. Situação similar ocorre na área de Matemática, em que o percentual médio de estudantes com desempenho abaixo do esperado entre as escolas com menor Inse foi de $80,4 \%$, enquanto o percentual médio foi de 16,7\% para as escolas de maior Inse.

O segundo gráfico da Figura 3 descreve a relação entre o Inse e o percentual de estudantes com desempenho desejável em cada escola. O quadro geral demonstra haver uma relação direta entre o nível socioeconômico da escola e o percentual de estudantes da instituição com desempenho desejável. Nota-se que, para o grupo de escolas de Inse muito baixo, o valor médio para o percentual de estudantes com desempenho desejável foi de apenas 4,9\% em Leitura e 10,7\% em Matemática. Já para as escolas com Inse muito alto, esses percentuais foram muito maiores, 36,2\% e $64,6 \%$, respectivamente.

A Figura A1 do Apêndice retrata, por meio de gráficos de caixa, a distribuição do percentual de estudantes com desempenho insuficiente, por escola, nas duas áreas avaliadas, separados de acordo com o grupo de nível socioeconômico. Observa-se que as medidas de posição (mediana e demais quartis) para o percentual de estudantes com desempenho insuficiente na escola apresentaram tendência de queda à medida que consideramos grupos de escolas com nível socioeconômico mais elevado. Essa situação demonstra o efeito dos componentes extraescolares na medida educacional, uma vez que os estímulos provenientes do ambiente familiar trarão benefícios aos estudantes no processo de aquisição de habilidades de Leitura e Matemática. Além disso, quanto maior o nível socioeconômico da escola, maior a probabilidade de que os pais dos estudantes possuam uma formação superior e uma renda suficientemente alta para propiciar tais estímulos.

Outro fator que pode afetar a aprendizagem dos estudantes é a adequação da formação de seus professores. Os gráficos apresentados na Figura 4 exploram a relação entre o percentual de docentes com formação adequada, que atuam no ensino fundamental nos anos iniciais, e o percentual de estudantes com desempenho suficiente e com desempenho desejável para a série avaliada, ambos agregados por instituição de ensino. Para essa análise considerou-se quase 40 mil escolas que tinham pelo menos $80 \%$ de participação na ANA e apresentavam o indicador AFD calculado. Os resultados mostram que escolas com maior percentual de professores com formação adequada apresentaram, em média, um menor percentual de estudantes com desempenho insuficiente. Observa-se que, para as escolas com menos de $30 \%$ dos docentes com formação em nível mais adequado para lecionar no ensino fundamental, o percentual médio de estudantes com desempenho insuficiente ficou acima de $30 \%$ 
em Leitura e em torno de 70\% em Matemática. Já para as escolas com mais de 75\% dos docentes com formação adequada, os percentuais médios nas duas áreas foram, respectivamente, 16,1\% e 48,5\%. Quanto ao nível de desempenho desejável, nota-se que as escolas com menor taxa de adequação na formação docente tiveram, em média, menor percentual de estudantes nesse nível em Leitura e Matemática do que as escolas com maiores taxas de adequação na formação de seus docentes.

\section{Insuficiente}

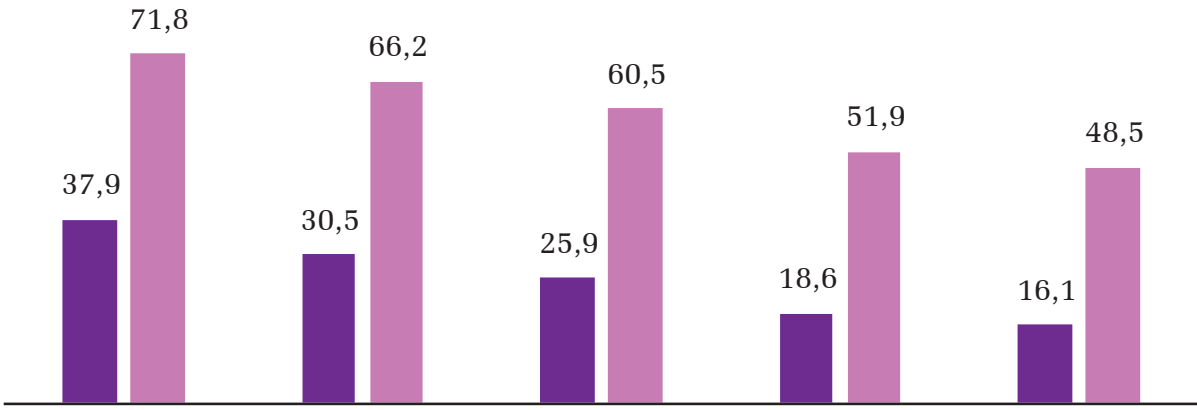

Até 15\% Entre 15 e 30\% Entre 30 e 50\% Entre 50 e 75\% Acima de $75 \%$

- Percentual de estudantes com desempenho insuficiente em Leitura

Percentual de estudantes com desempenho insuficiente em Matemática

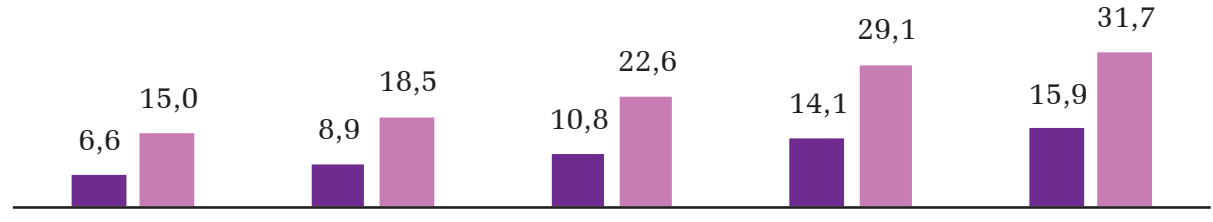

Até $15 \%$ Entre 15 e 30\% Entre 30 e 50\% Entre 50 e 75\% Acima de $75 \%$

- Percentual de estudantes com desempenho desejável em Leitura

- Percentual de estudantes com desempenho desejável em Matemática

FIGURA 4

\section{PERCENTUAL MÉDIO DE ESTUDANTES COM DESEMPENHO INSUFICIENTE E COM DESEMPENHO DESEJÁVEL NAS ESCOLAS, POR NIIVEL DE ADEQUAÇÃO DA FORMAÇÃO DOCENTE DA ESCOLA}

Fonte: Elaboração própria com base em microdados da ANA (Brasil. Inep, 2016b).

Na Tabela B1 do Apêndice são apresentados os coeficientes de correlação de Pearson dos percentuais de estudantes com desempenho insuficiente e dos percentuais de estudantes com desempenho desejável, tanto em Leitura quanto em Matemática, com a taxa de adequação da formação docente, por escola. Todas as correlações foram significativas ao nível de 1\%. Quando consideramos o percentual de estudantes com 
desempenho insuficiente, a relação é negativa, o que indica que quanto maior for a adequação, menor tende a ser a proporção de estudantes com desempenho insuficiente. Quando se olha para a proporção de estudantes com desempenho desejável, essa relação é direta, ou seja, quanto maior a taxa de docentes com formação adequada, maior a chance de que a escola apresente um maior percentual de estudantes com desempenho desejável. Esses coeficientes variaram, em módulo, entre 0,25 e 0,35, apontando para uma correlação fraca. No Apêndice, Figura A2, são apresentados os gráficos de caixa com a distribuição do percentual de estudantes com desempenho insuficiente nas duas áreas, separados de acordo com o nível do percentual de docentes com formação adequada. Os resultados mostram que, quanto maior o percentual de professores com formação adequada, menores serão os valores dos quartis das variáveis que mensuram o percentual de estudantes com desempenho insuficiente em Leitura e Matemática.

Além das relações entre os indicadores calculados no nível da escola, também se procurou explorar a relação entre os índices de alfabetização ${ }^{17}$ e os indicadores de contexto do município. Os indicadores de contexto escolhidos para essa análise foram: o índice de desenvolvimento humano municipal (IDHM) ${ }^{18}$ de 2010 , o produto interno bruto (PIB) per capita de 2016, o coeficiente de desigualdade de Gini $^{19}$ de 2010 e o tamanho da população projetado para 2016. Para essas análises foram considerados aproximadamente 5.500 municípios que tiveram taxa de participação na ANA de, pelo menos, $50 \%$ de seus estudantes do $3^{\circ}$ ano do ensino fundamental ${ }^{20}$.

A Tabela B2 do Apêndice traz os coeficientes de correlação linear entre os percentuais de estudantes com desempenho insuficiente e com desempenho desejável, e os indicadores de contexto do município. Todos os coeficientes estimados foram significativos ao nível de 1\%, exceto para o tamanho da população, o qual não apresentou correlação com os indicadores de alfabetização. Para os demais indicadores, as maiores correlações ocorreram para o IDHM e seus componentes. Na maioria dos casos, os coeficientes estimados foram, em módulo, superiores a 0,6, indicando a existência de uma correlação moderada. Para o coeficiente de Gini, as correlações estimadas variaram, em módulo, entre 0,39 e 0,48, o que também representa uma correlação moderada. Para o PIB per capita, os coeficientes de correlação apontaram para uma relação mais fraca, com coeficientes variando entre 0,26 e 0,34.

\footnotetext{
${ }^{17}$ Os índices de alfabetização foram calculados por município e representam o percentual de estudantes com desempenho insuficiente em Leitura e em Matemática e o percentual de estudantes com desempenho desejável nessas duas áreas.

${ }^{18}$ Detalhes sobre o IDHM podem ser encontrados em: < https://www.br.undp.org/content/brazil/pt/home/ idho/conceitos/o-que-e-o-idhm.html>.

${ }^{19}$ Coeficiente criado pelo estatístico Corrado Gini em 1912 e utilizado para mensurar a desigualdade de distribuição de renda. O índice varia entre 0 e 1 e quanto maior seu valor maior é a concentração de renda.

${ }^{20}$ A taxa de participação dos municípios foi definida na Portaria Inep nº 410, de 22 de julho de 2016, em seu art. 11, alínea b.
} 


\section{Insuficiente}

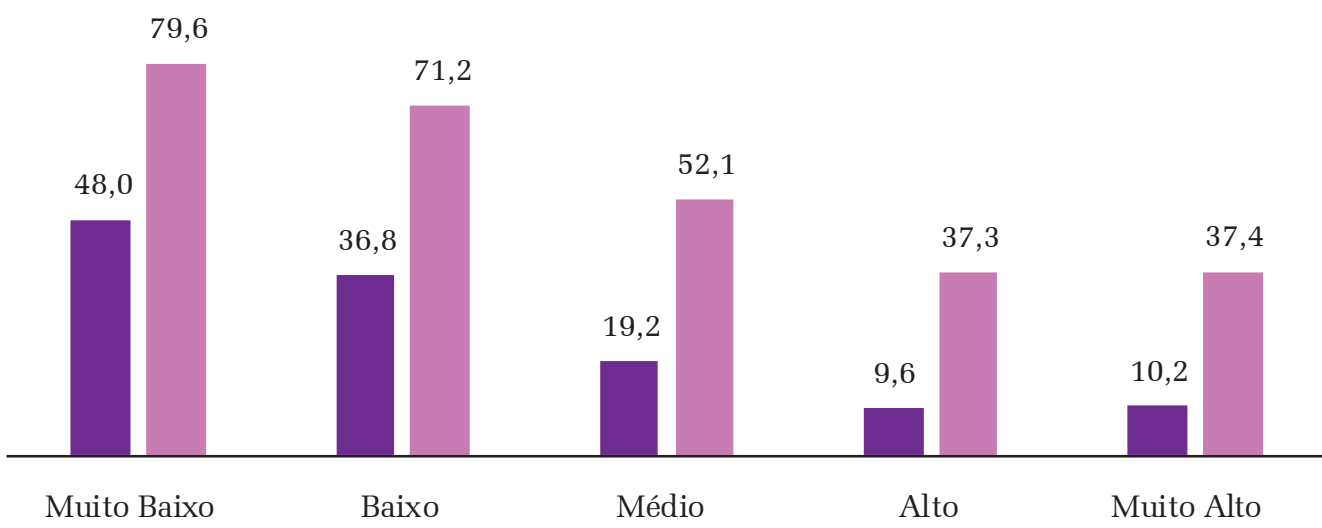

Percentual de estudantes com desempenho insuficiente em Leitura

Percentual de estudantes com desempenho insuficiente em Matemática

\section{Desejável}

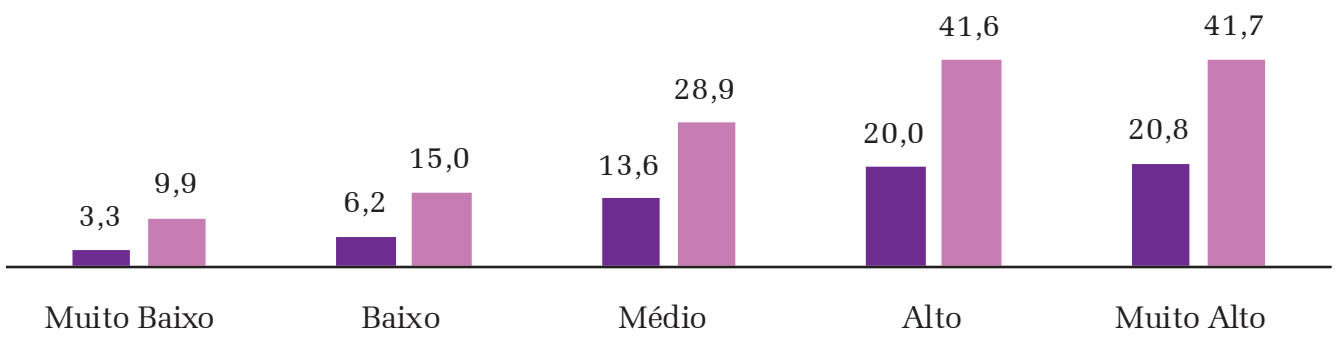

Percentual de estudantes com desempenho desejável em Leitura

Percentual de estudantes com desempenho desejável em Matemática

FIGURA 5

\section{PERCENTUAL MÉDIO DE ESTUDANTES COM DESEMPENHO INSUFICIENTE E COM DESEMPENHO DESEJÁVEL NO MUNICÍPIO, POR NÍVEL DE IDHM DO MUNICÍPIO}

Fonte: Elaboração própria com base em microdados da ANA (Brasil. Inep, 2016b) e em dados do IDHM Pnud/Unesco 2010 (Atlas do Desenvolvimento Humano no Brasil, [s. d.]).

Para descrever melhor as correlações lineares obtidas a partir da Tabela B2, foram incluídas algumas análises gráficas exploratórias. A Figura 5 descreve a relação entre o IDHM e o percentual de estudantes do município com desempenho insuficiente (à esquerda) e com desempenho desejável (à direita). Nota-se que, para os municípios classificados com IDHM muito baixo, quase metade dos estudantes tiveram desempenho insuficiente em Leitura e $80 \%$ não atingiram o desempenho esperado em Matemática. Já para os municípios classificados com IDHM alto ou muito alto, o percentual médio de estudantes com desempenho insuficiente foi de apenas $10 \%$ 
em Leitura e menos de 40\% em Matemática. Resultados compatíveis são observados quando se considera o percentual médio de estudantes com desempenho desejável. Os municípios com IDHM mais elevado apresentaram, em média, um percentual maior de estudantes com desempenho desejável. Além dos valores médios, é possível verificar na Figura A3 do Apêndice a distribuição dos municípios quanto ao percentual de estudantes com desempenho insuficiente em Leitura e em Matemática, por nível do IDHM. Observa-se nessa figura que os quartis para o percentual de estudantes com desempenho insuficiente foram menores para os municípios com níveis de IDHM alto e muito alto quando comparados aos grupos de municípios classificados com níveis de IDHM baixo ou muito baixo. Os municípios com IDHM médio ficaram em uma situação intermediária em relação ao desempenho dos estudantes.
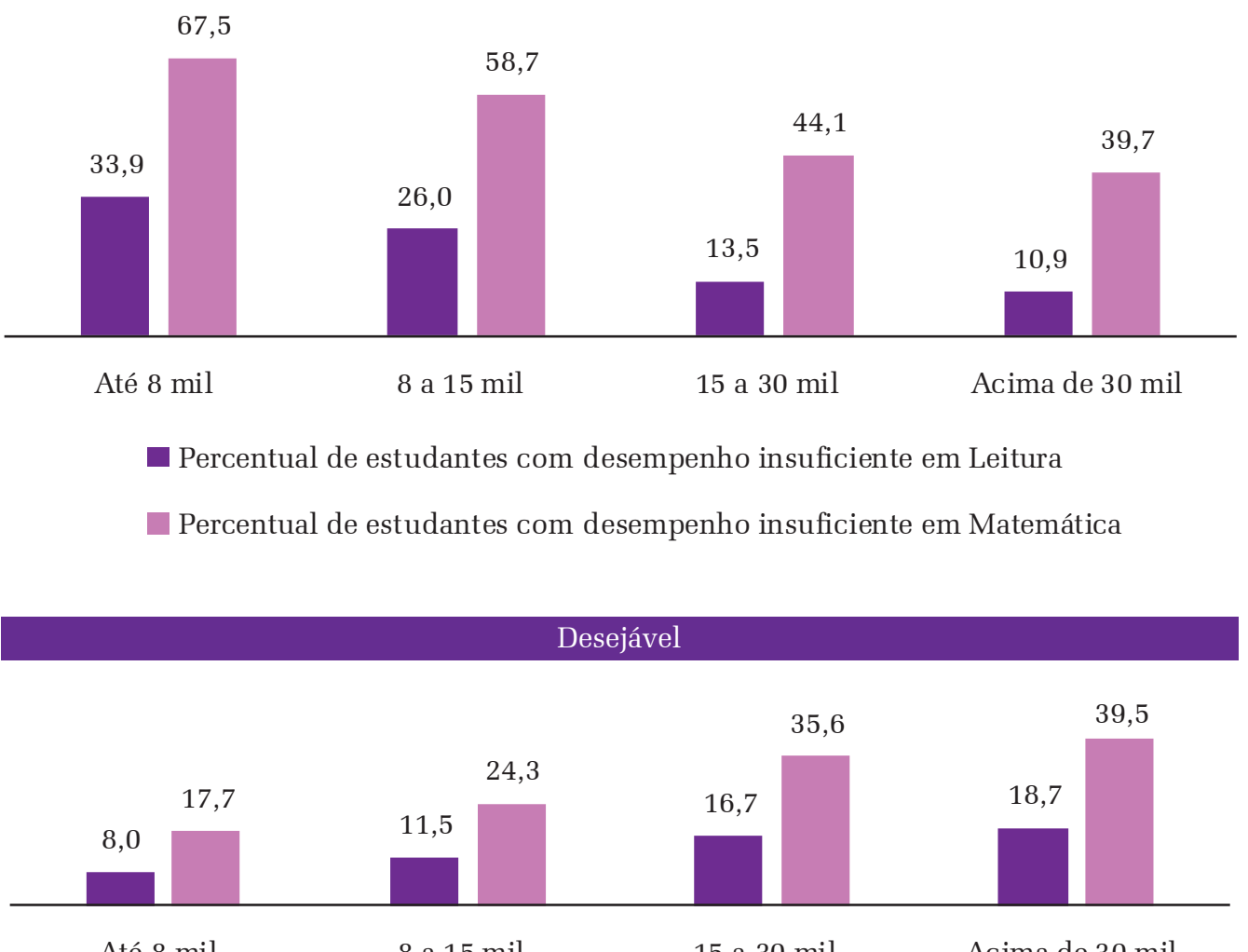

Até $8 \mathrm{mil}$

8 a 15 mil

15 a $30 \mathrm{mil}$

Acima de 30 mil

Percentual de estudantes com desempenho desejável em Leitura

Percentual de estudantes com desempenho desejável em Matemática

FIGURA 6

\begin{abstract}
PERCENTUAL MÉDIO DE ESTUDANTES COM DESEMPENHO INSUFICIENTE E COM DESEMPENHO DESEJÁVEL NO MUNICÍPIO, POR NÍVEL DE PIB PER CAPITA DO MUNICÍPIO
\end{abstract}

Fonte: Elaboração própria com base em microdados da ANA (Brasil. Inep, 2016b) e em dados do PIB per capita (IBGE, 2016). 
A Figura 6 explora a relação entre os índices de alfabetização e o PIB per capita. Nota-se que os municípios com maior renda tendem a apresentar menor percentual médio de estudantes com desempenho insuficiente e maior percentual de estudantes com resultado desejável. Por exemplo, entre os municípios de menor renda, o percentual médio de estudantes com conhecimento abaixo do esperado foi de aproximadamente 35\% em Leitura e de quase 70\% em Matemática. Já entre os municípios de maior renda esses percentuais foram, respectivamente, de 10,9\% e de 39,7\%. A Figura A4 do Apêndice retrata a distribuição dos municípios quanto ao percentual de estudantes com desempenho insuficiente em Leitura e em Matemática, por nível de renda. Nota-se que os municípios com PIB per capita inferior a 15 mil reais anuais têm um comportamento bem distinto daqueles com renda superior a esse valor. O conjunto de municípios com PIB per capita mais elevado apresentaram mediana e demais quartis com valores bem menores que o grupo de municípios com menor PIB per capita. Esses resultados indicam que os municípios de maior renda tendem a apresentar um menor percentual de estudantes com desempenhos insuficiente nas duas áreas avaliadas.

Outro fator que pode estar relacionado aos índices de alfabetização do município é o grau de concentração da renda. Para explorar essa relação, utilizou-se o coeficiente de desigualdade de Gini. A Figura 7 traz o valor médio para o percentual de estudantes com desempenho insuficiente (à esquerda) e desejável (à direita) em Leitura e em Matemática, separados por grupos de municípios de acordo com o coeficiente de Gini. É possível notar que o percentual médio de estudantes com resultados insatisfatórios é maior no conjunto de municípios com níveis mais elevados de desigualdade de renda. Para o grupo de municípios com melhor distribuição na renda (Gini < 0,04), o percentual médio de estudantes com baixo desempenho foi de 8,1\% na área de Leitura e de 34,3\% em Matemática. Já no grupo com maior concentração de renda (Gini > 0,6), esses percentuais médios atingiram, respectivamente, 32,6\% e 67,4\% dos estudantes. Para o grupo de estudantes com nível desejável, nota-se que municípios com maior concentração na renda apresentam um menor percentual médio de estudantes com níveis de aprendizagem desejável. Além disso, a Figura A5 do Apêndice contém os gráficos de caixa com a distribuição do percentual de estudantes com desempenho insuficiente nos munícipios, por nível de desigualdade. Nota-se que há uma tendência de aumento nos valores das medidas de posição (mediana e demais quartis) para o percentual de estudantes com desempenho insuficiente, à medida que se considera grupos de municípios com índices mais elevados de desigualdade. Esse comportamento se repete nas duas áreas de conhecimento avaliadas, indicando que municípios com alta concentração de renda tendem a ter piores índices em relação à alfabetização. 


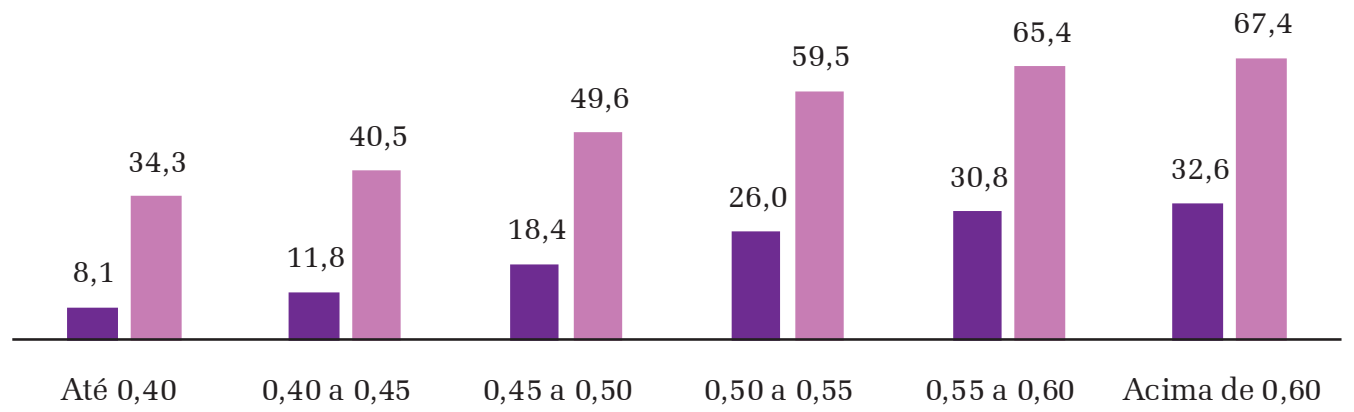

Percentual de estudantes com desempenho insuficiente em Leitura

Percentual de estudantes com desempenho insuficiente em Matemática

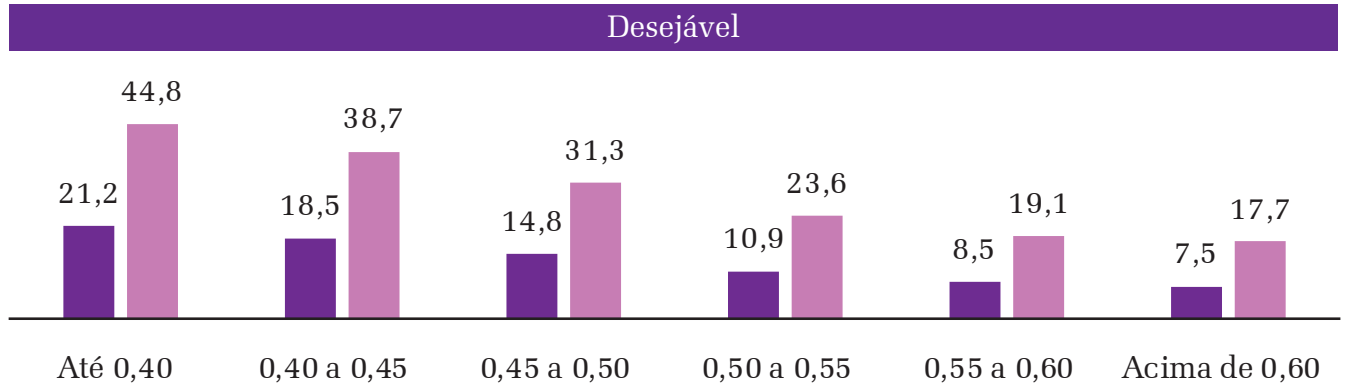

Percentual de estudantes com desempenho desejável em Leitura

Percentual de estudantes com desempenho desejável em Matemática

FIGURA 7

\section{PERCENTUAL MÉDIO DE ESTUDANTES COM DESEMPENHO INSUFICIENTE E COM DESEMPENHO DESEJÁVEL NO MUNICÍPIO, POR NÍVEL DE DESIGUALDADE MEDIDO A PARTIR DO COEFICIENTE DE GINI DO MUNICÍPIO}

Fonte: Elaboração própria com base em microdados da ANA (Brasil. Inep, 2016b) e no Censo Demográfico IBGE/2010 (Atlas do Desenvolvimento Humano no Brasil, [s. d.]).

Por fim, a Figura 8 traz o percentual médio de estudantes com desempenho insuficiente (à esquerda) e com desempenho desejável (à direita) nas duas áreas avaliadas, de acordo com o número de habitantes do município. Os resultados observados nos dois gráficos indicam que o tamanho do município medido a partir da quantidade de habitantes parece não ter relação com os indicadores de alfabetização explorados. Esse resultado é reforçado pela análise de correlação feita anteriormente, em que os coeficientes de correlação linear, além de não significativos, ficaram muito próximos de zero. 


\section{Insuficiente}

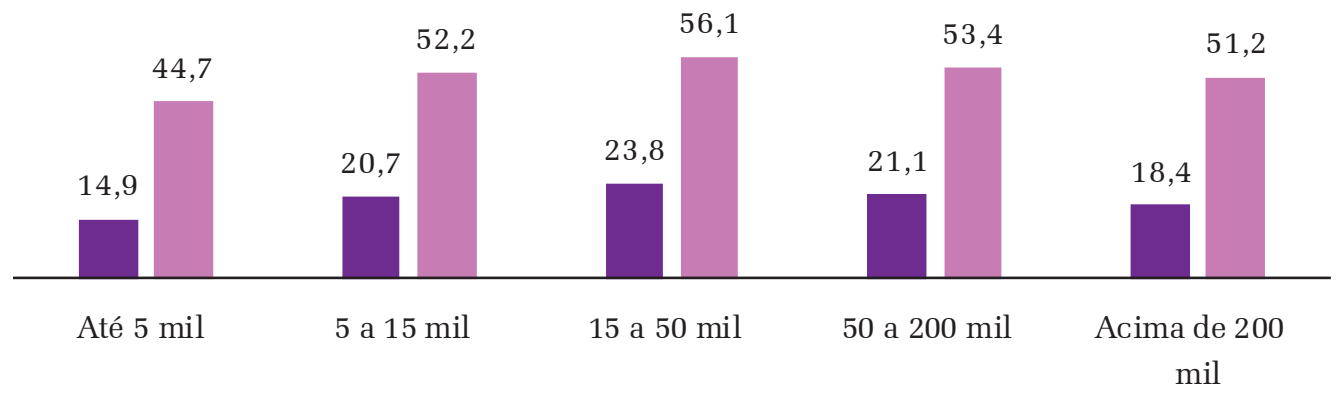

Percentual de estudantes com desempenho insuficiente em Leitura

Percentual de estudantes com desempenho insuficiente em Matemática

\section{Desejável}

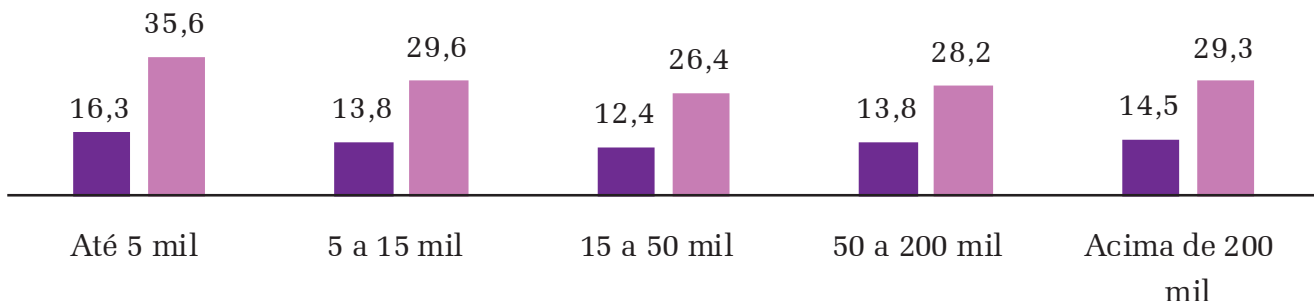

Percentual de estudantes com desempenho desejável em Leitura

Percentual de estudantes com desempenho desejável em Matemática

FIGURA 8

\section{PERCENTUAL MÉDIO DE ESTUDANTES COM DESEMPENHO INSUFICIENTE E COM DESEMPENHO DESEJÁVEL NO MUNICÍPIO, POR TAMANHO DA POPULAÇÃO DO MUNICÍPIO}

Fonte: Elaboração própria com base em microdados da ANA (Brasil. Inep, 2016b) e em dados de população do IBGE (2016).

\section{CONSIDERAÇÕES FINAIS}

As breves análises realizadas neste estudo demostram que o Brasil apresenta um cenário delicado em relação à alfabetização, especialmente na área de Matemática, em que mais da metade dos estudantes avaliados apresentaram desempenho abaixo do esperado para o $3^{\circ}$ ano. Essa situação é ainda mais preocupante para as regiões Norte e Nordeste, para a zona rural, para as escolas que atendem às populações mais carentes e para os municípios com baixo índice de desenvolvimento humano, com baixa renda e com altos índices de desigualdade. Contudo, essas análises são de ordem exploratória e abordam apenas alguns aspectos, sendo necessário avaliar outras dimensões que 
podem contribuir para o processo de aprendizagem, tais como: rotatividade de docentes; formação e valorização dos docentes, especialmente daqueles que atuam em área rural e em comunidades mais pobres; adequação da infraestrutura escolar; disponibilidade e utilização de recursos pedagógicos; e políticas de gestão das escolas, que ainda sofrem com estratégias políticas de nomeação de seus diretores.

Nossos resultados reafirmam as hipóteses de influência do contexto socioeconômico no resultado dos estudantes. Tal relação se encontra em toda a literatura pela influência que a escolarização dos pais e o acesso à cultura formal por meios de estímulos no ambiente familiar podem ter na trajetória escolar. Embora tenhamos considerado, sobretudo, os aspectos socioeconômicos e a formação docente, não se ignora que os outros elementos macroestruturais do contexto escolar também possuam algum efeito sobre o sucesso escolar. Mais que uma associação direta, a manutenção de boas estruturas nas escolas, o reconhecimento do nível socioeconômico dos estudantes e o investimento em formação e valorização de professores auxiliam a garantia do direito à educação e devem ser sempre objeto de atenção das redes. Nesse caso, optamos por uma análise preliminar relacionando o nível socioeconômico das escolas com seus índices de alfabetização, para identificar instituições que se destacam em cada condição, para posterior fase desta pesquisa.

Dessa maneira, verifica-se a necessidade de expandir o estudo para investigar, por exemplo, as escolas que possuem bons desempenhos em municípios com baixo nível de renda, assim como aquelas que possuem desempenhos abaixo do esperado em situação de maiores condições socioeconômicas. Este estudo viabilizará uma maior compreensão sobre aspectos do sucesso escolar na alfabetização que, provavelmente, se vinculam às práticas pedagógicas adotadas em cada instituição, ou mesmo a elementos estruturais que não foram contemplados nessa primeira etapa do estudo. Compreende-se por práticas pedagógicas as estratégias utilizadas pelos docentes para alcançar os objetivos de aprendizagem para aquela etapa.

Outro ponto que precisa de maiores discussões diz respeito à elucidação dos aspectos que compõem, complexamente, as políticas públicas em alfabetização. Nesse momento, o Pnaic está extinto, tendo sido substituído pela PNA (Brasil, 2019).

A nova política de alfabetização não favorece muito a autonomia pedagógica das escolas e busca introduzir uma estratégia de ensino padronizada, comum a todo território nacional. Não esclarece, porém, qual é o problema a ser solucionado, haja vista que o diagnóstico de analfabetismo feito até o momento não se dedicou a dizer qual domínio de leitura os estudantes possuem. O que se verifica é que se parte de um diagnóstico exagerado de analfabetismo no Brasil, tomando por base uma classificação parcialmente equivocada das escalas da ANA (2016). Contudo, nem essa base do trabalho da política está bem explicitada. No caderno de apresentação da PNA (2019), os dados são apenas mencionados superficialmente. Misturam-se aos dados da ANA aqueles provenientes do Programa Internacional de Avaliação de Estudantes (Pisa), apenas para concluir que os estudantes se encontram com dificuldades no 
desempenho de habilidades de leitura, sem qualificar quais seriam as deficiências apresentadas.

Compreende-se que faltam evidências e uma correta interpretação dos resultados para o anúncio do caos estabelecido na alfabetização, bem como na proposta de solução que, no atual momento, reside apenas na ênfase da adoção coletiva do método fônico. Ignoram-se o pacto federativo e as diversas especialidades do professor, buscando resolver um problema que não existe: o diagnóstico sem evidência de que os estudantes não sabem decodificar.

É possível compreender, a partir dos dados apresentados pela ANA, no campo estrito da alfabetização como definida no decreto que institui a PNA, que pouco se avançou em termos de compreensão da leitura em sua maior dimensão: o letramento. A leitura de palavras e, geralmente, a capacidade de decodificar estão representadas no primeiro nível da escala de Leitura, em que se classificou pouco mais de $20 \%$ da população. Seria, então, plausível tentar identificar se há a necessidade de investimento em métodos que aprimorem a decodificação ou se seria necessário avançar em termos de compreensão textual, que é a maior dificuldade que nossos estudantes apresentam na área de Leitura.

A PNA dedica maior atenção à aquisição de habilidades em Leitura e Escrita por meio de um método específico, o que pode significar uma redução da política de alfabetização com a hierarquização das disciplinas, relegando a área de Matemática a segundo plano, demonstrando uma limitação da atual política educacional brasileira. De acordo com Windle e Batista, na nova PNA:

A alfabetização é definida, em termos instrumentais, como "o ato de ensinar as habilidades de leitura e escrita em um sistema alfabético, de forma que o leitor se torne apto a ler e escrever palavras e textos com autonomia e entendimento" (Art. 2.I), e letramento como "a conjunção de conhecimento, habilidades e atitudes relacionadas à leitura e escrita e suas práticas produtivas" (Art. 2.VII). As 11 definições providas na introdução da Política evitam referências a qualquer contexto social para produção ou uso de textos, relacionando a alfabetização apenas a matemática e pais (uma sinalização positiva ao movimento de educação domiciliar, repetidos nos Artigos 3, 5 e 8). A habilidade de leitura é medida em "precisão, velocidade e prosódia”, (Art. 2.IV), separado de compreensão, diálogo e fazer sentido. (Windle; Batista, 2019, p. 396, tradução nossa).

Além de uma ausência de menção significativa à área de Matemática, a concepção de alfabetização apresentada no texto é limitada, reduzindo a alfabetização a uma capacidade de leitura sem ênfase na interpretação ou na capacidade de compreensão ampliada do que se lê.

Os dados apresentados demonstram o enorme déficit que os estudantes possuem na área de Matemática em todos os estados e regiões do País. Apesar desse cenário, a PNA faz pouca menção à área, ignorando os dados apresentados pela avaliação. 
Ainda que tenhamos ressaltado que a política de alfabetização deva ser direcionada para as instituições alocadas em contextos de baixo nível socioeconômico, em zonas rurais e em municípios mais pobres, com maior desigualdade de renda e com menor IDH, há a necessidade de aprofundamento sobre o impacto das práticas pedagógicas. Isso porque, mesmo em cenários adversos, são encontradas instituições e redes com resultados bastante efetivos na aprendizagem de seus estudantes, como é o caso do estado do Ceará. Se a política de alfabetização pode, portanto, ter algum efeito sobre a aprendizagem dos estudantes, interessa saber quais práticas podem contribuir para o alcance dos melhores resultados. O próximo passo desta pesquisa consistirá em investigar as práticas pedagógicas e outras estruturas encontradas em escolas que se destacam em seus contextos socioeconômicos. Acredita-se que as evidências coletadas poderão lançar luz às políticas educacionais mais direcionadas à melhoria geral do processo ensino-aprendizagem, demonstrando que as ações voltadas ao sucesso escolar dificilmente se beneficiam de visões restritivas que elegem apenas um elemento como decisivo para sua conquista.

\section{REFERÊNCIAS}

ATLAS DO DESENVOLVIMENTO HUMANO NO BRASIL. Base de dados. [s. d.]. Disponível em: < http://www.atlasbrasil.org.br/2013/pt/download/>. Acesso em: 11 nov. 2019.

BOF, A. M. A aprendizagem dos alunos e os desafios do PNE. Brasília: Inep, 2016.

BRASIL. Lei no 13.005 , de 25 de junho de 2014. Aprova o Plano Nacional de Educação - PNE e dá outras providências. Diário Oficial da União, Brasília, DF, 26 jun. 2014. Seção 1, p. 1.

BRASIL. Decreto n ${ }^{0}$ 9.765, de 11 de abril de 2019. Institui a Política Nacional de Alfabetização. Diário Oficial da União, Brasília, DF, 11 abr. 2019. Seção 1, p. 15. Edição extra.

BRASIL. Congresso Nacional. Câmara dos Deputados. Grupo de trabalho alfabetização infantil: os novos caminhos: relatório final. 2. ed. Brasília: Câmara dos Deputados/Coordenação de Publicações, 2007.

BRASIL. Instituto Nacional de Estudos e Pesquisas Educacionais Anísio Teixeira (Inep). Avaliação Nacional da Alfabetização: documento básico. Brasília, 2013a. Disponível em: <http://download.inep.gov.br/educacao_basica/saeb/2013/livreto_ ANA_online.pdf >. Acesso em: 6 nov. 2019. 
BRASIL. Instituto Nacional de Estudos e Pesquisas Educacionais Anísio Teixeira (Inep). Nota explicativa [da] Avaliação Nacional da Alfabetização - ANA 2013. Brasília, 2013b. Disponível em: < http://download.inep.gov.br/educacao_basica/saeb/ ana/resultados/2013/nota_explicativa_ana_2013.pdf>. Acesso em: 6 nov. 2019.

BRASIL. Instituto Nacional de Estudos e Pesquisas Educacionais Anísio Teixeira (Inep). Portaria n ${ }^{\circ}$ 410, de 22 de julho de 2016. Diário Oficial da União, Brasília, DF, 25 jul. 2016a. Seção 1, p. 393.

BRASIL. Instituto Nacional de Estudos e Pesquisas Educacionais Anísio Teixeira (Inep). Microdados: ANA. 2016b. Disponível em: < http://portal.inep.gov.br/web/ guest/microdados >. Acesso em: 11 nov. 2019.

BRASIL. Instituto Nacional de Estudos e Pesquisas Educacionais Anísio Teixeira (Inep). Relatório SAEB/ANA 2016: panorama do Brasil e dos estados. Brasília: Inep, 2018.

BRASIL. Instituto Nacional de Estudos e Pesquisas Educacionais Anísio Teixeira (Inep). Portaria $\mathrm{n}^{0}$ 366, de 29 de abril de 2019. Estabelece as diretrizes de realização do Sistema de Avaliação da Educação Básica (SAEB) no ano de 2019. Diário Oficial da União, Brasília, DF, 2 maio 2019. Seção 1, p. 1. Edição extra.

BRASIL. Ministério da Educação (MEC). Parâmetros Curriculares Nacionais: língua portuguesa: $1^{\mathrm{a}}$ a $4^{\mathrm{a}}$ séries. 3. ed. Brasília, 2001. v. 2.

BRASIL. Ministério da Educação (MEC). Conselho Nacional de Educação (CNE). Parecer CNE/CEB no 11/2010. Diretrizes Curriculares Nacionais para o Ensino Fundamental de 9 (nove) anos. Diário Oficial da União, Brasília, DF, 9 dez. 2010. Seção 1, pág. 28.

BRASIL. Ministério da Educação (MEC). Portaria nº 867, de 4 de julho de 2012. Institui o Pacto Nacional pela Alfabetização na Idade Certa e as ações do Pacto e define suas diretrizes gerais. Diário Oficial da União, Brasília, DF, 5 jul. 2012. Seção 1, p. 22.

BRASIL. Ministério da Educação (MEC). Portaria nº 482, de 7 de junho de 2013. Dispõe sobre o Sistema de Avaliação da Educação Básica - SAEB. Diário Oficial da União, Brasília, DF, 10 jun. 2013. Seção 1, p. 17.

BRASIL. Ministério da Educação (MEC). Portaria nº 1.144, de 10 de outubro de 2016. Institui o Programa Novo Mais Educação, que visa melhorar a aprendizagem em língua portuguesa e em matemática no ensino fundamental. Diário Oficial da União, Brasília, DF, 11 out. 2016. Seção 1, p. 23. 
BRASIL. Ministério da Educação (MEC). Base Nacional Comum Curricular: educação infantil e ensino fundamental. Brasília: MEC/SEB, 2017.

BRASIL. Ministério da Educação (MEC). Portaria nº 4, de 4 de janeiro de 2018. Institui o Programa Mais Alfabetização, que visa fortalecer e apoiar as unidades escolares no processo de alfabetização dos estudantes regularmente matriculados nos $1^{\circ}$ e $2^{\circ}$ anos iniciais do ensino fundamental. Diário Oficial da União, Brasília, DF, 5 jan. 2018. Seção 1, p. 15.

BRASIL. Ministério da Educação (MEC). Política Nacional de Alfabetização. Brasília: MEC/SEALF, 2019.

CENTRAL ADVISORY COUNCIL FOR EDUCATION (England). Children and their primary school. London: HMSO, 1967.

CENTRO DE ALFABETIZAÇÃO, LEITURA E ESCRITA (CEALE). Carta aberta em defesa do Pnaic: fórum das universidades públicas participantes do Programa se posiciona perante críticas recentes ao Programa. Belo Horizonte, 2015. Disponível em: <http://www.ceale.fae.ufmg.br/pages/view/carta-aberta-em-defesa-do-pnaic. html>. Acesso em: 6 nov. 2019.

COLEMAN, J. S. et al. Equality of educational opportunity. Washington, DC: US Government Printing Office, 1966.

INSTITUTO BRASILEIRO DE GEOGRAFIA E ESTATÍSTICA (IBGE). Produto Interno Bruto dos municípios. 2016. Disponível em: <https://www.ibge.gov.br/estatisticas/ economicas/contas-nacionais/9088-produto-interno-bruto-dos-municipios. html $?=\& \mathrm{t}=$ resultados $>$. Acesso em: 11 nov. 2019.

OBSERVATÓRIO DO PNE. Alfabetização: alfabetizar todas as crianças, no máximo, até o final do $3^{\circ}$ ano do ensino fundamental [escrita]. 2016a. Disponível em: $<$ https://observatoriodopne.org.br/indicadores/metas/5-alfabetizacao/indicadores/ porcentagem-de-criancas-do-3-ano-do-ensino-fundamental-com-aprendizagemadequada-em-escrita/\#indicadores >. Acesso em: 12 nov. 2019.

OBSERVATÓRIO DO PNE. Alfabetização: alfabetizar todas as crianças, no máximo, até o final do $3^{\circ}$ ano do ensino fundamental [leitura]. 2016b. Disponível em: <https://www.observatoriodopne.org.br/indicadores/metas/5-alfabetizacao/ indicadores >. Acesso em: 12 nov. 2019.

OBSERVATÓRIO DO PNE. Alfabetização: alfabetizar todas as crianças, no máximo, até o final do $3^{\circ}$ ano do ensino fundamental [matemática]. 2016c. Disponível em: $<$ https://observatoriodopne.org.br/indicadores/metas/5-alfabetizacao/indicadores/ 
porcentagem-de-criancas-do-3-ano-do-ensino-fundamental-com-aprendizagemadequada-em-matematica/\#indicadores >. Acesso em: 12 nov. 2019.

OLIVEIRA, J. B. A. Construtivismo e alfabetização: um casamento que não deu certo. Ensaio: Avaliação e Políticas Públicas em Educação, Rio de Janeiro, v. 35, p. 161-200, 2000 .

SOARES, M. Alfabetização e letramento. 7. ed. São Paulo: Contexto, 2017.

WINDLE, J.; BATISTA, S. A circulação global de políticas de alfabetização: o método fônico, desigualdade e movimentos políticos neoconservadores. Revista Brasileira de Linguística Aplicada, Belo Horizonte, v. 19, n. 2, p. 385-406, abr./jun. 2019. 



\section{APÊNDICE}

\section{APÊNDICE A - FIGURAS}

\section{Leitura}

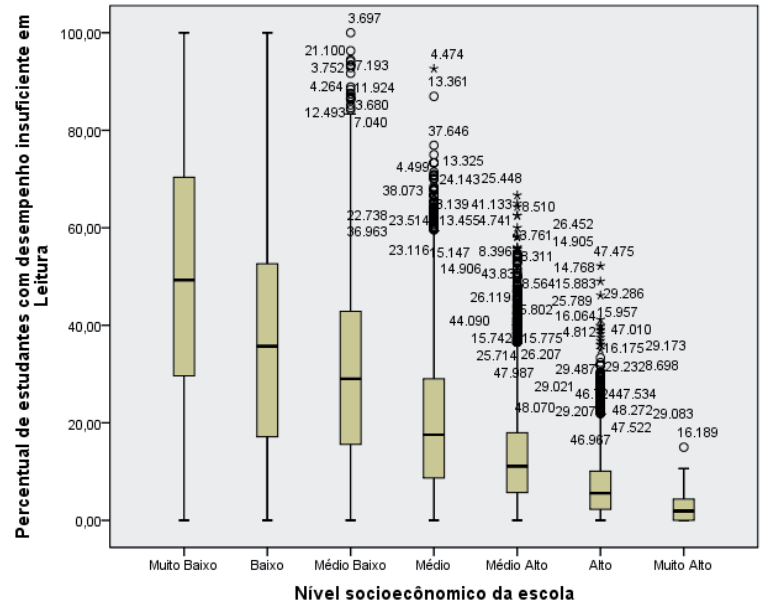

Matemática

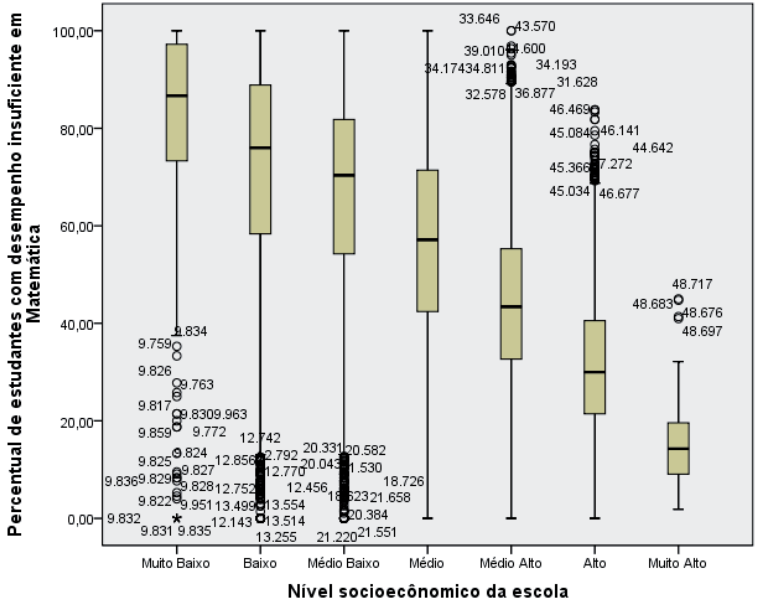

FIGURA A1

DISTRIBUIÇÃO DO PERCENTUAL DE ESTUDANTES DA ESCOLA COM DESEMPENHO INSUFICIENTE EM LEITURA E EM MATEMÁTICA, POR NÍVEL SOCIOECONÔMICO DA ESCOLA

Fonte: Elaboração própria com base em microdados da ANA (Brasil. Inep, 2016b). 


\section{Leitura}

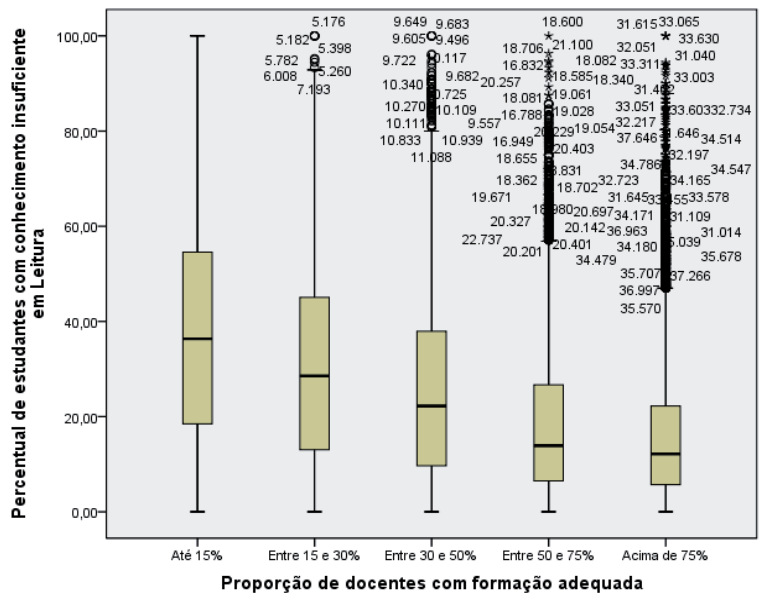

\section{Matemática}

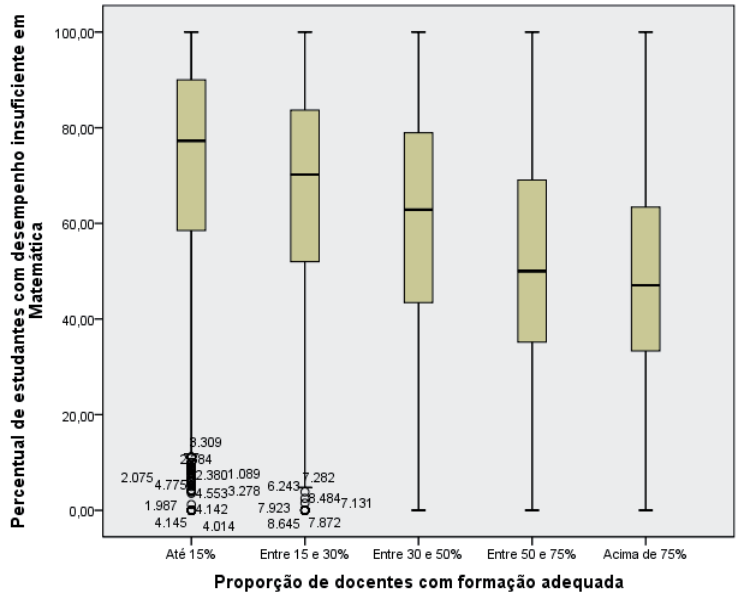

FIGURA A2

\section{DISTRIBUIÇÃO DO PERCENTUAL DE ESTUDANTES DA ESCOLA COM DESEMPENHO INSUFICIENTE EM LEITURA E EM MATEMÁTICA, POR NIIVEL DE ADEQUAÇÃO DA FORMAÇÃO DOCENTE DA ESCOLA}

Fonte: Elaboração própria com base em microdados da ANA (Brasil. Inep, 2016b). 


\section{Leitura}

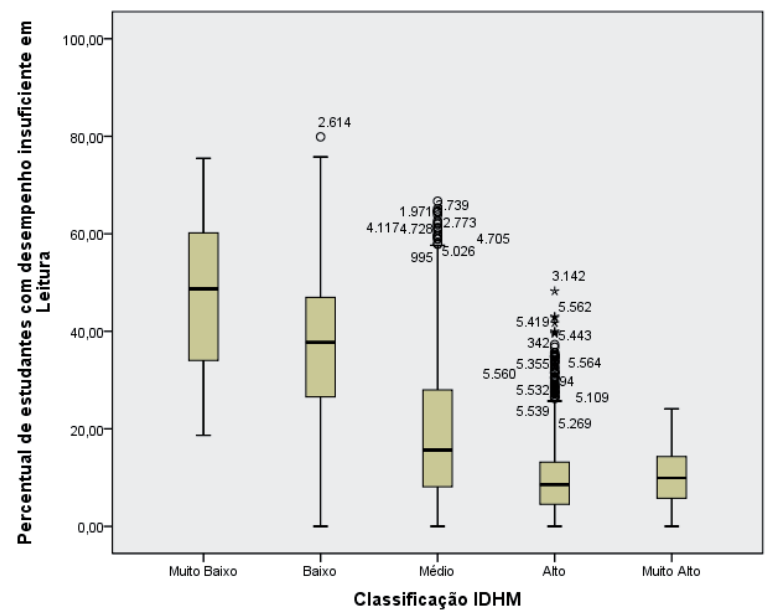

Matemática

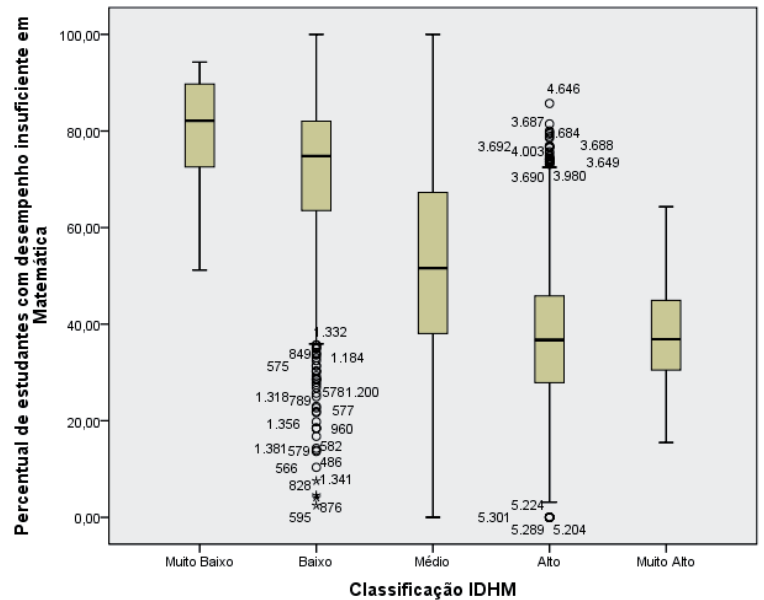

FIGURA A3

DISTRIBUIÇÃO DO PERCENTUAL DE ESTUDANTES DO MUNICÍPIO COM DESEMPENHO INSUFICIENTE EM LEITURA E EM MATEMÁTICA, POR NIIVEL DE IDHM DO MUNICÍPIO

Fonte: Elaboração própria com base em microdados da ANA (Brasil. Inep, 2016b) e em dados do IDHM Pnud/Unesco 2010 (Atlas do Desenvolvimento Humano no Brasil, [s. d.]). 


\section{Leitura}

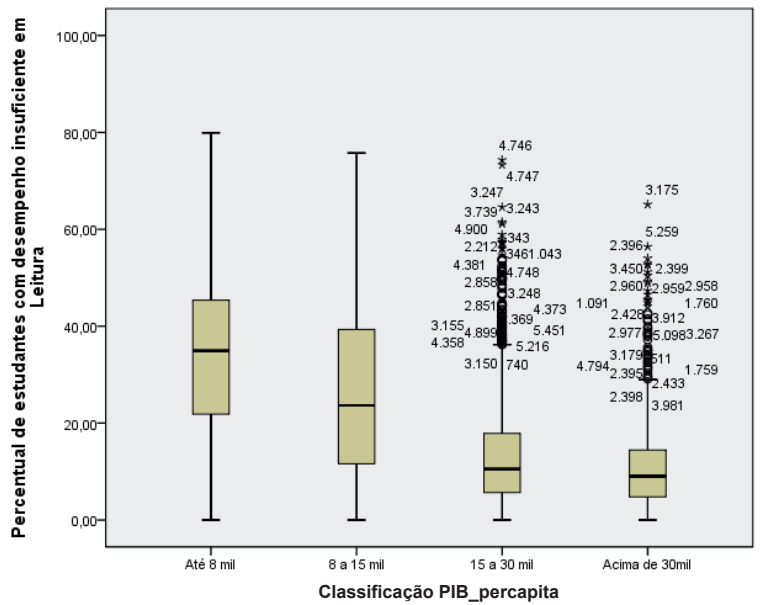

\section{Matemática}

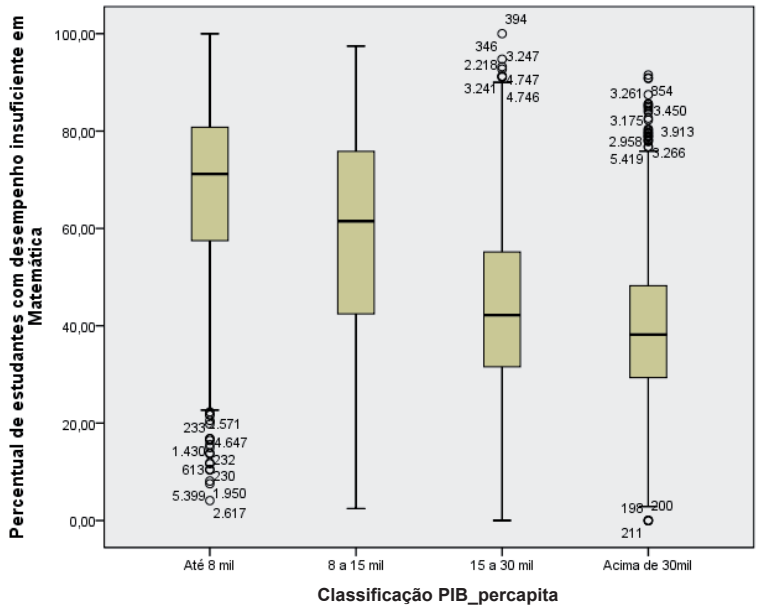

FIGURA A4

DISTRIBUIÇÃO DO PERCENTUAL DE ESTUDANTES DO MUNICÍPIO COM DESEMPENHO INSUFICIENTE EM LEITURA E EM MATEMÁTICA, POR NÍVEL DE PIB PER CAPITA DO MUNICÍPIO

Fonte: Elaboração própria com base em microdados da ANA (Brasil. Inep, 2016b) e em dados do PIB per capita (IBGE, 2016). 


\section{Leitura}

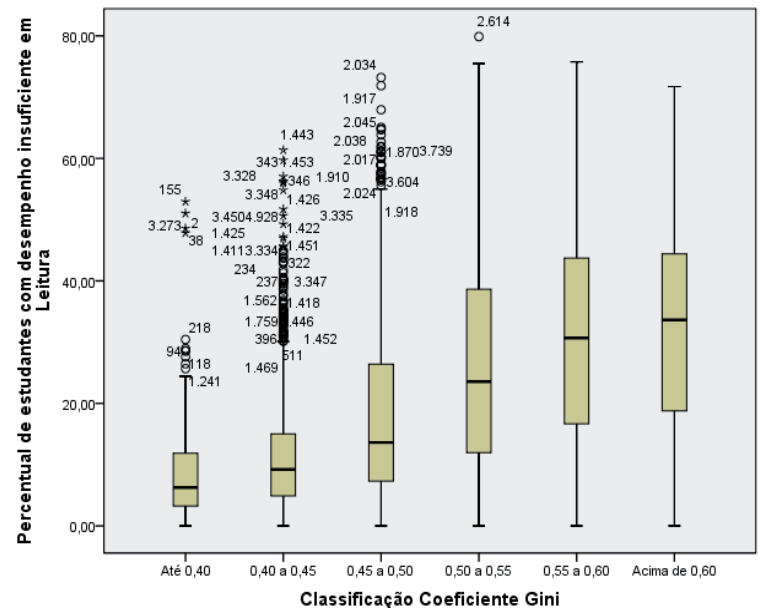

Matemática

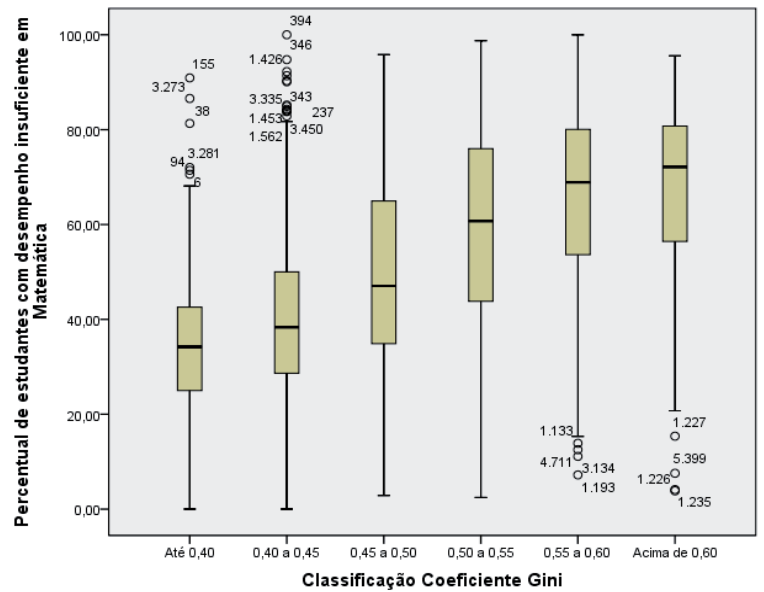

FIGURA A5

DISTRIBUIÇÃO DO PERCENTUAL DE ESTUDANTES DO MUNICÍPIO COM DESEMPENHO INSUFICIENTE EM LEITURA E EM MATEMÁTICA, POR NÍVEL DE DESIGUALDADE MEDIDO A PARTIR DO COEFICIENTE DE GINI DO MUNICÍPIO

Fonte: Elaboração própria com base em microdados da ANA (Brasil. Inep, 2016b) e no Censo Demográfico IBGE/2010 (Atlas do Desenvolvimento Humano no Brasil, [s. d.]). 


\section{APÊNDICE B - TABELAS}

TABELA B1

\section{CORRELAÇÃO DE PEARSON ENTRE O PERCENTUAL DE ESTUDANTES DA ESCOLA COM DESEMPENHO INSSUFICIENTE E COM DESEMPENHO DESEJÁVEL EM LEITURA E MATEMÁTICA E A TAXA DE ADEQUAÇÃO DA FORMAÇÃO DOCENTE DA ESCOLA}

\begin{tabular}{|c|c|c|c|c|c|}
\hline & & $\begin{array}{c}\text { Percentual de } \\
\text { estudantes com } \\
\text { desempenho } \\
\text { insuficiente em } \\
\text { Leitura }\end{array}$ & $\begin{array}{c}\text { Percentual de } \\
\text { estudantes com } \\
\text { desempenho } \\
\text { desejável em } \\
\text { Leitura }\end{array}$ & $\begin{array}{c}\text { Percentual de } \\
\text { estudantes com } \\
\text { desempenho } \\
\text { insuficiente em } \\
\text { Matemática }\end{array}$ & $\begin{array}{l}\text { Percentual de } \\
\text { estudantes com } \\
\text { desempenho } \\
\text { desejável em } \\
\text { Matemática }\end{array}$ \\
\hline \multirow{3}{*}{$\begin{array}{l}\text { Adequação } \\
\text { da Formação } \\
\text { Docente }\end{array}$} & $\begin{array}{l}\text { Correlação } \\
\text { de Pearson }\end{array}$ & $-0,348$ & 0,242 & $-0,316$ & 0,277 \\
\hline & Valor - p & $<0,001$ & $<0,001$ & $<0,001$ & $<0,001$ \\
\hline & $\begin{array}{l}\text { Total de } \\
\text { escolas }\end{array}$ & 38270 & 38270 & 40874 & 40874 \\
\hline
\end{tabular}

Fonte: Elaboração própria com base em microdados da ANA (Brasil. Inep. 2016b).

TABELA B2

CORRELAÇÃO DE PEARSON ENTRE O PERCENTUAL DE ESTUDANTES DO MUNICÍPIO COM DESEMPENHO INSUFICIENTE E COM DESEMPENHO DESEJÁVEL NAS ÁREAS DE LEITURA E MATEMÁTICA E OS INDICADORES DE CONTEXTO DO MUNICÍPIO

(continua)

\begin{tabular}{|c|c|c|c|c|c|}
\hline & & $\begin{array}{l}\text { Percentual de } \\
\text { estudantes com } \\
\text { desempenho } \\
\text { insuficiente em } \\
\text { Leitura }\end{array}$ & $\begin{array}{l}\text { Percentual de } \\
\text { estudantes com } \\
\text { desempenho } \\
\text { desejável em } \\
\text { Leitura }\end{array}$ & $\begin{array}{l}\text { Percentual de } \\
\text { estudantes com } \\
\text { desempenho } \\
\text { insuficiente em } \\
\text { Matemática }\end{array}$ & $\begin{array}{l}\text { Percentual de } \\
\text { estudantes com } \\
\text { desempenho } \\
\text { desejável em } \\
\text { Matemática }\end{array}$ \\
\hline \multirow{3}{*}{ IDHM } & $\begin{array}{l}\text { Correlação } \\
\text { de Pearson }\end{array}$ & $-0,678$ & 0,550 & $-0,660$ & 0,617 \\
\hline & Valor - p & $<0,001$ & $<0,001$ & $<0,001$ & $<0,001$ \\
\hline & $\begin{array}{l}\text { Total de } \\
\text { municípios }\end{array}$ & 5503 & 5503 & 5507 & 5507 \\
\hline \multirow{3}{*}{$\begin{array}{l}\text { IDHM } \\
\text { Educação }\end{array}$} & $\begin{array}{l}\text { Correlação } \\
\text { de Pearson }\end{array}$ & $-0,605$ & 0,508 & $-0,598$ & 0,560 \\
\hline & Valor - p & $<0,001$ & $<0,001$ & $<0,001$ & $<0,001$ \\
\hline & $\begin{array}{l}\text { Total de } \\
\text { municípios }\end{array}$ & 5503 & 5503 & 5507 & 5507 \\
\hline \multirow{3}{*}{$\begin{array}{l}\text { IDHM } \\
\text { Longevidade }\end{array}$} & $\begin{array}{l}\text { Correlação } \\
\text { de Pearson }\end{array}$ & $-0,654$ & 0,527 & $-0,630$ & 0,589 \\
\hline & Valor - p & $<0,001$ & $<0,001$ & $<0,001$ & $<0,001$ \\
\hline & $\begin{array}{l}\text { Total de } \\
\text { municípios }\end{array}$ & 5503 & 5503 & 5507 & 5507 \\
\hline
\end{tabular}


TABELA B2

\section{CORRELAÇÃO DE PEARSON ENTRE O PERCENTUAL DE ESTUDANTES DO MUNICÍPIO COM DESEMPENHHO INSUFICIENTE E COM DESEMPENHO DESEJÁVEL NAS ÁREAS DE LEITURA E MATEMÁTICA E OS INDICADORES DE CONTEXTO DO MUNICÍPIO}

(conclusão)

\begin{tabular}{|c|c|c|c|c|c|}
\hline & & $\begin{array}{c}\text { Percentual de } \\
\text { estudantes com } \\
\text { desempenho } \\
\text { insuficiente em } \\
\text { Leitura }\end{array}$ & $\begin{array}{c}\text { Percentual de } \\
\text { estudantes com } \\
\text { desempenho } \\
\text { desejável em } \\
\text { Leitura }\end{array}$ & $\begin{array}{l}\text { Percentual de } \\
\text { estudantes com } \\
\text { desempenho } \\
\text { insuficiente em } \\
\text { Matemática }\end{array}$ & $\begin{array}{c}\text { Percentual de } \\
\text { estudantes com } \\
\text { desempenho } \\
\text { desejável em } \\
\text { Matemática }\end{array}$ \\
\hline \multirow{3}{*}{$\begin{array}{l}\text { IDHM_- } \\
\text { Renda }\end{array}$} & $\begin{array}{l}\text { Correlação } \\
\text { de Pearson }\end{array}$ & $-0,661$ & 0,518 & $-0,638$ & 0,595 \\
\hline & Valor - p & $<0,001$ & $<0,001$ & $<0,001$ & $<0,001$ \\
\hline & $\begin{array}{l}\text { Total de } \\
\text { municípios }\end{array}$ & 5503 & 5503 & 5507 & 5507 \\
\hline \multirow{3}{*}{$\begin{array}{l}\text { PIB_- } \\
\text { percapita }\end{array}$} & $\begin{array}{l}\text { Correlação } \\
\text { de Pearson }\end{array}$ & $-0,337$ & 0,255 & $-0,322$ & 0,301 \\
\hline & Valor - p & $<0,001$ & $<0,001$ & $<0,001$ & $<0,001$ \\
\hline & $\begin{array}{l}\text { Total de } \\
\text { municípios }\end{array}$ & 5508 & 5508 & 5512 & 5512 \\
\hline \multirow{3}{*}{ População } & $\begin{array}{l}\text { Correlação } \\
\text { de Pearson }\end{array}$ & 0,002 & $-0,007$ & 0,010 & $-0,016$ \\
\hline & Valor - p & 0,868 & 0,616 & 0,455 & 0,238 \\
\hline & $\begin{array}{l}\text { Total de } \\
\text { municípios }\end{array}$ & 5508 & 5508 & 5512 & 5512 \\
\hline \multirow{3}{*}{ GINI } & $\begin{array}{l}\text { Correlação } \\
\text { de Pearson }\end{array}$ & 0,461 & $-0,392$ & 0,477 & $-0,457$ \\
\hline & Valor - p & $<0,001$ & $<0,001$ & $<0,001$ & $<0,001$ \\
\hline & $\begin{array}{l}\text { Total de } \\
\text { municípios }\end{array}$ & 5503 & 5503 & 5507 & 5507 \\
\hline
\end{tabular}

Fonte: Elaboração própria com base em microdados da ANA (Brasil. Inep, 2016b), no Censo Demográfico IBGE/2010 (Atlas do Desenvolvimento Humano no Brasil, [s. d.]), em dados do PIB per capita e de população (IBGE, 2016) e do IDHM Pnud/Unesco (Atlas do Desenvolvimento Humano no Brasil, [s. d]). 


\section{ANEXOS}

\section{ANEXO A - ESCALA DE PROFICIÊNCIA EM LEITURA}

\begin{tabular}{|c|c|c|}
\hline Nível & Desempenho & Descrição \\
\hline \multirow[b]{2}{*}{1} & \multirow{2}{*}{$\begin{array}{l}\text { até } 425 \\
\text { pontos }\end{array}$} & Neste nível, os estudantes provavelmente são capazes de: \\
\hline & & $\begin{array}{l}\text { * Ler palavras com estrutura silábica canônica, não canônica e ainda que } \\
\text { alternem sílabas canônicas e não canônicas. }\end{array}$ \\
\hline \multirow{5}{*}{2} & \multirow{5}{*}{$\begin{array}{l}\text { maior que } \\
425 \text { até } 525 \\
\text { pontos }\end{array}$} & $\begin{array}{l}\text { Além das habilidades descritas no nível anterior, o estudante provavelmente } \\
\text { é capaz de: }\end{array}$ \\
\hline & & $\begin{array}{l}\text { * Localizar informações explícitas em textos curtos como piada, parlenda, } \\
\text { poema, quadrinho, fragmentos de narrativas e de curiosidade científica. Em } \\
\text { textos de maior extensão, quando a informação está localizada na primeira } \\
\text { linha do texto; }\end{array}$ \\
\hline & & $\begin{array}{l}\text { * Reconhecer a finalidade de texto como convite, cartaz, receita, bilhete, } \\
\text { anúncio com ou sem apoio de imagem; }\end{array}$ \\
\hline & & $\begin{array}{l}\text { * Identificar assunto de um cartaz apresentado em sua forma original e ainda } \\
\text { em textos cujo assunto pode ser identificado no título ou na primeira linha; }\end{array}$ \\
\hline & & $\begin{array}{l}\text { * Inferir sentido em piada e em história em quadrinhos que articula linguagem } \\
\text { verbal e não verbal. }\end{array}$ \\
\hline \multirow[b]{4}{*}{3} & \multirow[b]{4}{*}{$\begin{array}{l}\text { maior que } \\
525 \text { até } 625 \\
\text { pontos }\end{array}$} & $\begin{array}{l}\text { Além das habilidades descritas no nível anterior, o estudante provavelmente } \\
\text { é capaz de: }\end{array}$ \\
\hline & & $\begin{array}{l}\text { * Localizar informação explícita em textos de maior extensão como fragmento } \\
\text { de literatura infantil, lenda, cantiga folclórica e poema, quando a informação } \\
\text { está localizada no meio ou ao final do texto; }\end{array}$ \\
\hline & & $\begin{array}{l}\text { * Identificar o referente de um pronome pessoal do caso reto em textos como } \\
\text { tirinha e poema narrativo; }\end{array}$ \\
\hline & & $\begin{array}{l}\text { * Inferir relação de causa e consequência em textos exclusivamente verbais - } \\
\text { piada, fábula, fragmentos de textos de literatura infantil e texto de curiosidade } \\
\text { científica - com base na progressão textual; e em textos que articulam a } \\
\text { linguagem verbal e não verbal - tirinha; sentido em história em quadrinhos } \\
\text { que articula linguagem verbal e não verbal com vocabulário específico de } \\
\text { textos de divulgação científica ou que exige conhecimento intertextual } \\
\text { de narrativas infantis; assunto de texto de extensão média de divulgação } \\
\text { científica para crianças, com base nos elementos que aparecem no início do } \\
\text { texto; significado de expressão de linguagem figurada em textos, como poema } \\
\text { narrativo, fragmentos de literatura infantil, de curiosidade científica e tirinha. }\end{array}$ \\
\hline \multirow{4}{*}{4} & \multirow{4}{*}{$\begin{array}{l}\text { maior que } \\
625 \text { pontos }\end{array}$} & $\begin{array}{l}\text { Além das habilidades descritas no nível anterior, o estudante provavelmente } \\
\text { é capaz de: }\end{array}$ \\
\hline & & $\begin{array}{l}\text { * Reconhecer relação de tempo em texto verbal e participantes de um diálogo } \\
\text { em uma entrevista ficcional. }\end{array}$ \\
\hline & & $\begin{array}{l}\text { * Identificar o referente de pronome possessivo em poema; o referente de } \\
\text { advérbio de lugar em reportagem; referente de expressão formada por } \\
\text { pronome demonstrativo em fragmento de texto de divulgação científica para } \\
\text { o público infantil; }\end{array}$ \\
\hline & & $\begin{array}{l}\text { * Inferir sentido em fragmento de conto; sentido de palavra em fragmento } \\
\text { de texto de literatura infantil; assunto em texto de extensão média ou longa, } \\
\text { considerando elementos que parecem ao longo do texto, em gêneros como } \\
\text { divulgação científica, curiosidade histórica para criança e biografia. }\end{array}$ \\
\hline
\end{tabular}

Fonte: Brasil. Inep (2018). 


\section{ANEXO B - ESCALA DE PROFICIÊNCIA EM ESCRITA}

Nível Desempenho

Em relação à escrita de palavras, os estudantes que se encontram neste nível provavelmente não escrevem as palavras ou estabelecem

1

Menor que 350 pontos

Maior ou igual a 350

2 pontos e menor que 450 pontos

3

Maior ou igual a 450 pontos e menor que 500 pontos

Maior ou igual a 500

4 pontos e menor que 600 pontos

Maior ou igual a 600 pontos algumas correspondências entre as letras grafadas e a pauta sonora, porém ainda não escrevem palavras alfabeticamente. Em relação à produção de textos, os estudantes provavelmente não escrevem o texto ou produzem textos ilegíveis.

Em relação à escrita de palavras, os estudantes que se encontram neste nível provavelmente escrevem alfabeticamente palavras com trocas ou omissão de letras, alterações na ordem das letras e outros desvios ortográficos. Em relação à produção de textos, os estudantes provavelmente não escrevem o texto ou produzem textos ilegíveis.

Em relação à escrita de palavras, os estudantes que se encontram neste nível provavelmente escrevem ortograficamente palavras com estrutura silábica consoante-vogal, apresentando alguns desvios ortográficos em palavras com estruturas silábicas mais complexas. Em relação à produção de textos, provavelmente escrevem de forma incipiente ou inadequada ao que foi proposto, sem as partes da história a ser contada, ou produzem fragmentos sem conectivos e/ ou recursos de substituição lexical e/ou pontuação para estabelecer articulações entre partes do texto. Apresentam ainda grande quantidade de desvios ortográficos e de segmentação ao longo do texto.

Em relação à escrita de palavras, os estudantes que se encontram neste nível provavelmente escrevem ortograficamente palavras com diferentes estruturas silábicas. Em relação à produção de textos, provavelmente atendem à proposta de dar continuidade a uma narrativa, embora possam não contemplar todos os elementos da narrativa e/ou partes da história a ser contada. Articulam as partes do texto com a utilização de conectivos, recursos de substituição lexical e outros articuladores, mas ainda cometem desvios que comprometem parcialmente o sentido da narrativa, inclusive por não utilizar a pontuação ou utilizar os sinais de modo inadequado. Além disso, o texto pode apresentar poucos desvios de segmentação e alguns desvios ortográficos que não comprometem a compreensão.

Em relação à escrita de palavras, os estudantes que se encontram neste nível provavelmente escrevem ortograficamente palavras com diferentes estruturas silábicas. Em relação à produção de textos, provavelmente atendem à proposta de dar continuidade a uma narrativa, evidenciando uma situação inicial, central e final, com narrador, espaço, tempo e personagens. Articulam as partes do texto com conectivos, recursos de substituição lexical e outros articuladores textuais. Segmentam e escrevem as palavras corretamente, embora o texto possa apresentar poucos desvios ortográficos e de pontuação que não comprometem a compreensão.

Fonte: Brasil. Inep (2018). 


\begin{tabular}{|c|c} 
& \\
& \\
& \\
& \\
& Menor que \\
$\mathbf{1}$ & 425 \\
& pontos
\end{tabular}

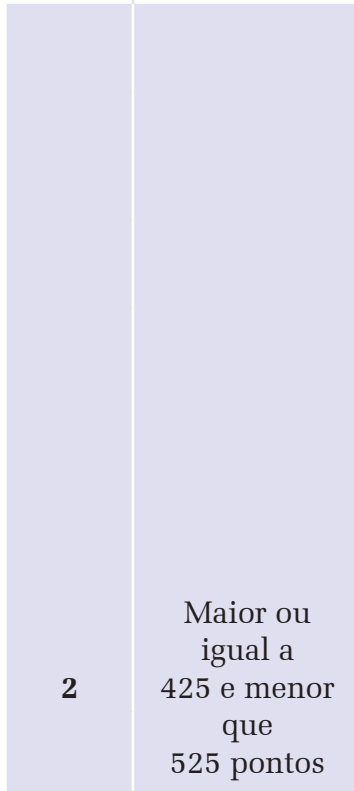

* Ler horas e minutos em relógio digital; medida em instrumento (termômetro, régua) com valor procurado explícito;

* Associar figura geométrica espacial ou plana à imagem de um objeto; contagem de até 20 objetos dispostos em forma organizada ou desorganizada à sua representação por algarismos;

* Reconhecer planificação de figura geométrica espacial (paralelepípedo);

* Identificar maior frequência em gráfico de colunas, com quatro categorias, ordenadas da maior para a menor;

* Comparar espessura de imagens de objetos; quantidades pela contagem, identificando a maior quantidade, em grupos de até 20 objetos organizados.

Além das habilidades descritas no nível anterior, os estudantes provavelmente são capazes de:

* Ler medida em instrumento (balança analógica) identificando o intervalo em

que se encontra a medida;

* Associar a escrita por extenso de números naturais com até 3 ordens à sua representação por algarismos.

* Reconhecer figura geométrica plana (triângulo, retângulo, quadrado e círculo) a partir de sua nomenclatura; valor monetário de cédulas ou de agrupamento de cédulas e moedas;

* Identificar o intervalo em que se encontra uma medida apresentada em um instrumento (balança analógica); registro de tempo em calendário; frequência associada a uma categoria em gráfico de colunas ou de barras, com quatro categorias; informação ou frequência associada a uma categoria em tabela simples ou de dupla entrada (com o máximo de 3 linhas e 4 colunas, ou 4 linhas e 3 colunas); a composição de um número natural de 2 algarismos, dada sua decomposição em ordens. *

* Comparar comprimento de imagens de objetos; quantidades pela contagem, identificando a maior quantidade, em grupos de até 20 objetos desorganizados; quantidades pela contagem, identificando quantidades iguais; números naturais não ordenados com até 3 algarismos.

* Completar sequências numéricas crescentes de números naturais, de 2 em 2, de 4 em 4, de 5 em 5 ou de 10 em 10.

* Calcular adição envolvendo dois números naturais de até 3 algarismos sem reagrupamento; subtração envolvendo dois números naturais de até 2 algarismos sem reagrupamento.

* Resolver problema de adição ou subtração envolvendo números naturais de até 2 algarismos, sem reagrupamento nos cálculos, com o significado de acrescentar ou retirar e em que o estado final é desconhecido; problema de multiplicação ou divisão envolvendo números naturais de até 2 algarismos, sem reagrupamento nos cálculos, com o significado de metade e em que o tamanho do grupo é desconhecido. 
Nível Desempenho

\begin{tabular}{|c|c|c|}
\hline \multirow{6}{*}{3} & \multirow{6}{*}{$\begin{array}{l}\text { Maior ou } \\
\text { igual a } \\
525 \text { e menor } \\
\text { que } \\
575 \text { pontos }\end{array}$} & $\begin{array}{l}\text { Além das habilidades descritas nos níveis anteriores, os estudantes } \\
\text { provavelmente são capazes de: }\end{array}$ \\
\hline & & $\begin{array}{l}\text { * Associar um agrupamento de cédulas e/ou moedas, com apoio de imagem ou } \\
\text { dado por meio de um texto, a outro com mesmo valor monetário. }\end{array}$ \\
\hline & & $\begin{array}{l}\text { * Identificar frequências iguais em gráfico de colunas, com quatro categorias; } \\
\text { gráfico de colunas que representa um conjunto de informações dadas em um } \\
\text { texto; frequência associada a uma categoria em tabela de dupla entrada (com } \\
\text { mais de } 4 \text { colunas, ou mais de } 4 \text { linhas). }\end{array}$ \\
\hline & & $\begin{array}{l}\text { * Completar sequência numérica decrescente de números naturais não } \\
\text { consecutivos. }\end{array}$ \\
\hline & & $\begin{array}{l}\text { * Calcular adição envolvendo dois números naturais de até } 3 \text { algarismos } \\
\text { e apenas um reagrupamento (na ordem das unidades ou das dezenas); } \\
\text { subtração envolvendo dois números naturais, em que pelo menos um deles } \\
\text { tem } 3 \text { algarismos, sem reagrupamento. }\end{array}$ \\
\hline & & $\begin{array}{l}\text { * Resolver problema de adição ou subtração envolvendo números } \\
\text { naturais de } 1 \text { ou } 2 \text { algarismos, com ou sem reagrupamento nos cálculos, } \\
\text { com o significado de retirar e em que o estado inicial ou o estado final é } \\
\text { desconhecido. }\end{array}$ \\
\hline \multirow[b]{6}{*}{4} & \multirow[b]{6}{*}{$\begin{array}{l}\text { Maior que } \\
575 \text { pontos }\end{array}$} & $\begin{array}{l}\text { Além das habilidades descritas nos níveis anteriores, os estudantes } \\
\text { provavelmente são capazes de: }\end{array}$ \\
\hline & & $\begin{array}{l}\text { * Inferir medida em instrumento (termômetro) com valor procurado não } \\
\text { explícito. }\end{array}$ \\
\hline & & $\begin{array}{l}\text { * Ler horas e minutos em relógios analógicos, identificando marcações de } \\
\text { 10, } 30 \text { e } 45 \text { minutos, além de horas exatas. }\end{array}$ \\
\hline & & $\begin{array}{l}\text { * Identificar composição ou decomposição aditiva de números naturais } \\
\text { com até } 3 \text { algarismos, canônica (mais usual, ex.: } 123=100+20+3 \text { ) ou } \\
\text { não canônica (ex.: } 123=100+23 \text { ); composição de um número natural de } \\
3 \text { algarismos, dada sua decomposição em ordens; uma categoria associada } \\
\text { a uma frequência específica em gráfico de barra, com quatro categorias. }\end{array}$ \\
\hline & & $\begin{array}{l}\text { * Calcular adição envolvendo dois números naturais de até } 3 \text { algarismos } \\
\text { e mais de um reagrupamento (na ordem das unidades e das dezenas); } \\
\text { subtração envolvendo dois números naturais com até } 3 \text { algarismos, com } \\
\text { reagrupamento. }\end{array}$ \\
\hline & & $\begin{array}{l}\text { * Resolver problema de adição ou subtração, envolvendo números naturais } \\
\text { de até } 3 \text { algarismos, com ou sem reagrupamento nos cálculos, com o } \\
\text { significado de comparar e em que a diferença, a menor ou a maior quantidade } \\
\text { seja desconhecida; problema de adição ou subtração, envolvendo números } \\
\text { naturais de até } 3 \text { algarismos, com reagrupamento nos cálculos, com o } \\
\text { significado de acrescentar e em que o estado inicial é desconhecido; problema } \\
\text { de multiplicação ou divisão envolvendo números naturais de até } 2 \text { algarismos, } \\
\text { com ou sem reagrupamento nos cálculos, com o significado de formação de } \\
\text { grupos iguais e em que o produto é desconhecido; problema de multiplicação } \\
\text { ou divisão envolvendo números naturais de até } 2 \text { algarismos, com apoio de } \\
\text { imagem ou não, com o significado de formação de grupos iguais e em que } \\
\text { o tamanho do grupo ou o número de grupos é desconhecido; problema de } \\
\text { multiplicação ou divisão envolvendo números naturais de até } 2 \text { algarismos, } \\
\text { sem reagrupamento nos cálculos, com o significado de comparar, incluindo } \\
\text { dobro ou triplo, em que a maior quantidade é desconhecida; problema de } \\
\text { multiplicação ou divisão envolvendo números naturais de } 2 \text { algarismos, com } \\
\text { o significado de comparar, incluindo terça ou quarta parte, em que a menor } \\
\text { quantidade é desconhecida. }\end{array}$ \\
\hline
\end{tabular}


